\title{
Reconciling regional nitrogen boundaries with global food security
}

\author{
Jinfeng Chang $\oplus^{1,2} \bowtie$, Petr Havlík $\oplus^{2}$, David Leclère $\oplus^{2}$, Wim de Vries $\oplus^{3}$, Hugo Valin $\oplus^{2}$, \\ Andre Deppermann ${ }^{2}$, Tomoko Hasegawa $\oplus^{4}$ and Michael Obersteiner ${ }^{2}{ }^{2}$
}

\begin{abstract}
While nitrogen inputs are crucial to agricultural production, excess nitrogen contributes to serious ecosystem damage and water pollution. Here, we investigate this trade-off using an integrated modelling framework. We quantify how different nitrogen mitigation options contribute to reconciling food security and compliance with regional nitrogen surplus boundaries. We find that even when respecting regional nitrogen surplus boundaries, hunger could be substantially alleviated with 590 million fewer people at risk of hunger from 2010 to 2050, if all nitrogen mitigation options were mobilized simultaneously. Our scenario experiments indicate that when introducing regional $\mathbf{N}$ targets, supply-side measures such as the nitrogen use efficiency improvement are more important than demand-side efforts for food security. International trade plays a key role in sustaining global food security under nitrogen boundary constraints if only a limited set of mitigation options is deployed. Policies that respect regional nitrogen surplus boundaries would yield a substantial reduction in non- $\mathrm{CO}_{2} \mathrm{GHG}_{\text {emissions of } 2.3 \mathrm{GtCO}_{2} \mathrm{e} \text { yr }}^{-1}$ in 2050, which indicates a necessity for policy coordination.
\end{abstract}

\section{T} he sufficiency of food production largely depends on the availability of reactive nitrogen $(\mathrm{Nr})$. Mineral $\mathrm{N}$ fertilizers play a key role in ensuring food security ${ }^{1}$ (United Nations Sustainable Development Goal (SDG) 2, 'Zero hunger'). N surpluses, defined as the $\mathrm{N}$ input into agricultural systems minus the $\mathrm{N}$ removal in agricultural products (crops, grass forage and animal products), are released to the environment. Excess $\mathrm{N}$ contributes to atmospheric pollution ${ }^{2,3}$ $\left(\mathrm{NH}_{3}\right.$ and $\mathrm{NO}_{x}$, hindering progress on SDG3, 'Good health and well-being'), vegetation degradation and biodiversity losses ${ }^{4}\left(\mathrm{NO}_{x}\right.$; SDG15, 'Life on land'), and climate change through $\mathrm{N}_{2} \mathrm{O}$ emissions (SDG13, 'Climate action'). Excess $\mathrm{N}$ also causes ground and surface water degradation ${ }^{6-8}$, mainly through $\mathrm{NO}_{3}{ }^{-}$surface runoff and leaching, and impacts freshwater (lakes) and marine ecosystems through river transport', critical to SDG6 ('Clean water and sanitation') and SDG14 ('Life below water'). N cycle management is thus an essential part of the wider sustainable development agenda.

The planetary nitrogen boundary ${ }^{10}$ has been substantially transgressed $^{11}$. In the absence of nitrogen mitigation actions, this environmental pressure will probably increase ${ }^{12}$. Despite the fact that this concept is debated ${ }^{13}$, we consider the global planetary nitrogen boundary as a good aggregate proxy of the severity of the problem. However, regional heterogeneity needs to be considered in the boundary definition $^{14,15}$. For example, in sub-Saharan Africa (except South Africa), the limited access to and affordability of synthetic $\mathrm{N}$ fertilizer currently keeps the $\mathrm{N}$ level in water in the 'safe' zone. In contrast, severe nitrogen-related water pollution has occurred in Europe ${ }^{16}$ and China ${ }^{17}$ due to high levels of mineral $\mathrm{N}$ fertilizer use (Europe and China), increased household wastes (China) and low nitrogen use efficiency (NUE) (China). Such regional risks call for translating the boundary framework to the regional level and accounting for each region's climatic, environmental and socio-economic circumstances.

Policies targeting the mitigation of $\mathrm{N}$ pollution have been successfully implemented in many regions and countries ${ }^{18}$. The role of
$\mathrm{Nr}$ in the future food supply has been investigated at regional ${ }^{19,20}$ and global levels ${ }^{19,21-23}$. However, the implications for food security of reaching environmental targets (for example, avoiding water pollution) have received less attention. Limiting $\mathrm{N}$ inputs without improving NUE may reduce food production, increase food prices and finally lead to hunger. De Vries et al. ${ }^{14}$ derived a global estimate of $\mathrm{Nr}$ inputs that respects food security and an $\mathrm{N}$ boundary to protect biodiversity, while calling for a detailed approach including representation of the full $\mathrm{N}$ cycle. Folberth et al. ${ }^{24}$ and Gerten et al. ${ }^{2.5}$ recently quantified the theoretical biophysical potential of providing sufficient food calories for the human population at the current level ${ }^{24}$ or for 10 billion people ${ }^{25}$ within multiple environmental boundaries, but without considering aspects of regional production, market effects and food security. Gerten et al. ${ }^{25}$ suggest the use of integrated assessment modelling as the next step.

Here, we provide an integrated global assessment of food security and regional $\mathrm{N}$ surplus boundaries accounting for a comprehensive set of food system drivers. We have developed a detailed representation of the N cycle (Fig. 1 and Methods) in a global land-use model, the Global Biosphere Management Model $\left(\mathrm{GLOBIOM}^{26}\right)$. In our approach, we assimilate the regional $\mathrm{N}$ surplus boundary with a critical $\mathrm{N}$ concentration in runoff (through surface runoff and leaching $\mathrm{N}$ flow) to surface waters from agricultural land of $2.5 \mathrm{mg} \mathrm{N}^{-1}$ following refs. ${ }^{27,28}$ (Methods). Four indicators informing on two dimensions of food security are used: two indicators for food availability (the mean dietary energy availability and the mean dietary protein availability) and two indicators for food access (the population at risk of hunger and the food price $)^{29}$. A set of scenarios was developed to help understand the trade-offs between environmental and food security targets: (1) a business-as-usual (BAU) scenario following the middle-of-the-road shared socio-economic pathway (SSP2; ref. ${ }^{30}$ ) as a baseline; and (2) a set of water quality protection scenarios where $\mathrm{N}$ surplus is constrained within regional $\mathrm{N}$ surplus boundaries (NrRB), differentiated by the assumptions about $\mathrm{N}$

${ }^{1}$ College of Environmental and Resource Sciences, Zhejiang University, Hangzhou, China. ${ }^{2}$ Ecosystems Services and Management Program (ESM), International Institute for Applied Systems Analysis (IIASA), Laxenburg, Austria. ${ }^{3}$ Environmental Systems Analysis Group, Wageningen University and Research, Wageningen, the Netherlands. ${ }^{4}$ College of Science and Engineering, Ritsumeikan University, Shiga, Japan. $₫$ e-mail: changjf@zju.edu.cn 


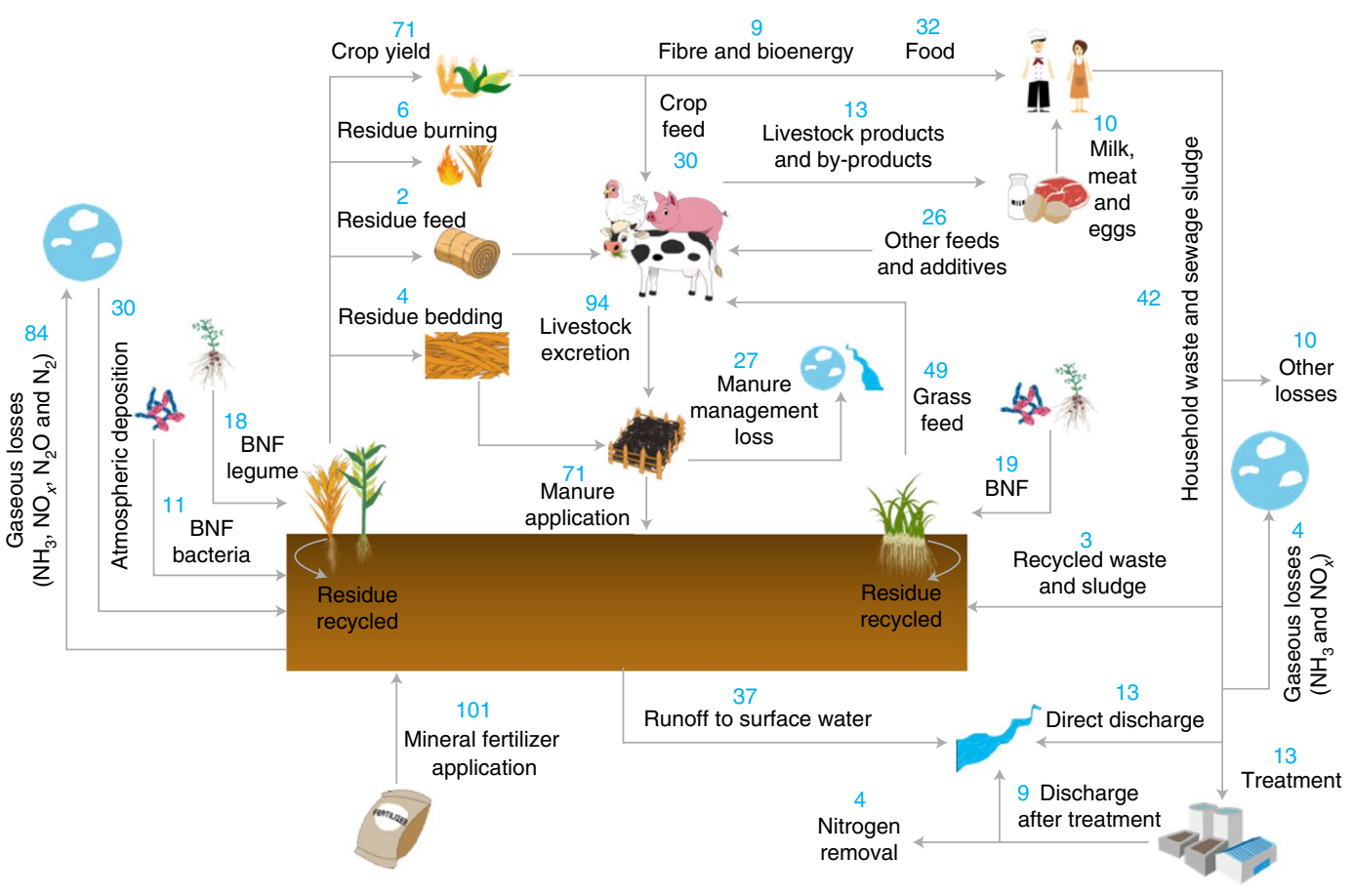

Fig. 1 | Illustration of modelled $\mathbf{N}$ flows and their magnitudes in 2010. The magnitudes in 2010 are indicated by the blue numbers (in Tg $\mathrm{Nyr}^{-1}$ ). Total livestock intake includes not only crops (30 $\mathrm{Tg} \mathrm{Nyr}^{-1}$ ), grasses (49 $\mathrm{Tg} \mathrm{Nyr}^{-1}$ ) and crop residues (stover; $2 \mathrm{Tg} \mathrm{Nyr}^{-1}$ ) but also occasional feed $\left(9 \mathrm{Tg} \mathrm{Nyr}^{-1}\right.$ ) and other feed and additives ( $18 \mathrm{Tg} \mathrm{Nyr}^{-1}$ ) that are assumed not to come from agricultural land. The crop-related $\mathrm{N}$ flow estimates are for food ( $32 \mathrm{Tg} \mathrm{Nyr}^{-1}$ ), feed $\left(30 \mathrm{Tg} \mathrm{Nyr}^{-1}\right)$ and other uses such as fibre products and bioenergy $\left(9 \mathrm{Tg} \mathrm{Nyr}^{-1}\right)$. Manure management losses include leaching $\left(3 \mathrm{Tg} \mathrm{Nyr}{ }^{-1}\right)$, gaseous losses $\left(\mathrm{NH}_{3}, \mathrm{NO}, \mathrm{N}_{2} \mathrm{O}\right.$ and $\left.\mathrm{N}_{2} ; 14 \mathrm{Tg} \mathrm{Nyr}^{-1}\right)$ and other uses $\left(10 \mathrm{Tg} \mathrm{Nyr}^{-1}\right)$. Losses of untreated household waste and sewage sludge consist of direct discharge of untreated sewage (13 $\left.\mathrm{Tg} \mathrm{Nyr}^{-1}\right)$, gaseous emissions from untreated sewage $\left(4 \mathrm{TgNyr}^{-1}\right)$, recycling to agricultural land $\left(3 \mathrm{Tg} \mathrm{Nyr} r^{-1}\right)$ and other

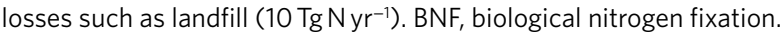

mitigation strategies in place, following the socio-economic driver assumptions of the BAU scenario (Table 1). To account for climate uncertainty, we ran a series of sensitivity simulations. Our scenarios do not explicitly address disruptors such as COVID-19. It remains unclear to what extent such events could have long-lasting impacts on agricultural markets ${ }^{31}$.

\section{Results}

Regional N surplus boundaries. We derived regional $\mathrm{N}$ surplus boundaries that, at the global scale, aggregate to $248 \mathrm{Tg} \mathrm{Nyr}^{-1}$ on the basis of a calculated critical $\mathrm{N}$ runoff (hereafter, $\mathrm{N}$ runoff stands for surface runoff and leaching $\mathrm{N}$ flow) to surface water, using a critical $\mathrm{N}$ load in runoff of $2.5 \mathrm{mg} \mathrm{N}^{-1}$ (Methods, Fig. 2 and Supplementary Table 5). We find that the regional critical $\mathrm{N}$ surplus has already been far exceeded in dry climate zones (the Middle East, North Africa and southern Europe) and in both high-N-input regions (India, China and western Europe) and low-NUE regions (India and China). Large reductions in $\mathrm{N}$ surplus (relative to the 2010 value) would be needed in these regions to stay within the regional $\mathrm{N}$ surplus boundary (Fig. 2). Agricultural expansion and intensification (for example, enhanced $\mathrm{N}$ inputs to improve crop yield) would be possible without exceeding the critical regional $\mathrm{N}$ concentration in runoff in Oceania, Southeast Asia, Latin America and the Caribbean, and sub-Saharan Africa (except South Africa). Such an expansion might, however, lead to undesirable impacts on soil and vegetation carbon stocks and biodiversity.

Food security implications with and without $\mathbf{N}$ constraints. Under the BAU scenario, global crop production and livestock production are projected to increase by $69 \%$ and $74 \%$ by 2050 compared with 2010 (Fig. 3a). International trade of crop products is projected to increase by $121 \%$, while trade of animal products would increase by $90 \%$ by 2050 , compared with 2010 (Fig. 3b). From 2010 to 2050, the largest increase in net crop import is projected in eastern Asia, followed by South Asia, the Middle East and North Africa, while Latin America and North America are projected to be the largest and second-largest exporting regions (Supplementary Fig. 1). Europe is projected to turn from a net importer in 2010 to a net exporter by 2050 . For animal products, the increase in net import from 2010 to 2050 is mainly by South Asia and sub-Saharan Africa, while Europe and Latin America would become major exporters (Supplementary Fig. 2). We calculated an increase in the global mean dietary energy availability of $14 \%$ (from $\sim 2,800$ to $3,200 \mathrm{kcal}$ per person per day; Fig. 4a), an increase in the global mean dietary protein availability of $14 \%$ (from 78 to $89 \mathrm{~g}$ protein per person per day; Fig. $4 \mathrm{~b}$ ) and a decrease in the population at risk of hunger from 824 million to 288 million from 2010 to 2050 (a reduction of 536 million; Fig. 4d). Food prices are projected to decrease in eastern Asia (-16\%) and developed regions ( $-1 \%$ to $-14 \%$; Supplementary Fig. 3), slightly increase in other developing regions (7\% to $12 \%)$, and decrease by $4 \%$ globally between 2010 and 2050 as improved productivity compensates for the food demand increase.

In the NrRB-BAU scenario, limiting regional $\mathrm{N}$ surplus below a critical boundary is projected to lead to $13 \%$ lower crop production and $13 \%$ lower livestock production by 2050 , compared with the BAU scenario (Fig. 3a). These values would result in food availability of $2,900 \mathrm{kcal}$ per capita per day and $80 \mathrm{~g}$ protein per capita per day globally by 2050 , food prices $26 \%$ higher than in 2010 , and a population of 741 million at risk of hunger $(8.1 \%$ of the 9.1 billion total population by 2050 under BAU, only 82 million fewer compared with 2010; Fig. 4a-d). 
Table 1 | Scenario assumptions, sustainability options and their direct effects on the food system and related $\mathrm{N}$ cycles

Scenarios and sustainability options

Baseline (BAU) Constant manure recycling as in 2000; a constant fraction Scenario assumptions

Direct effects of the sustainability options on the food system and related $\mathrm{N}$ cycles

of the population connected to wastewater treatment systems $(D)$ and $\mathrm{N}$ removal rate; no recycling of $\mathrm{N}$ from human wastewater treatment; BAU diet change following GDP development; BAU changes in NUE'.

NrRB-BAU

Constrained by regional $\mathrm{N}$ surplus boundaries without dedicated $\mathrm{N}$ surplus mitigation strategies (that is, with $\mathrm{N}$ assumptions the same as the BAU scenario).

NrRB-NUE (achieving Constrained by regional $\mathrm{N}$ surplus boundaries with the target NUE) regional NUE of cropland reaching the target NUEs of ref. ${ }^{50}$ by 2050 with a linear progression towards that target starting in 2010. For regions where the baseline NUE (for the year 2010) calculated by the model is higher than the target NUEs of ref. ${ }^{50}$, no NUE changes are applied.

NrRB-Manure (improving manure recycling)

Constrained by regional $\mathrm{N}$ surplus boundaries with a minimum of $90 \%$ of the manure excretion from grazed grassland being collected and managed by $2050^{\mathrm{b}}$ and a $50 \%$ reduction in $\mathrm{N}$ loss during manure management ${ }^{c}$, with a linear progression towards that target starting in 2010.

NrRB-Sewage (improving sewage treatment and recycling)

NrRB-FoodWaste (less harvest loss and food waste)

NrRB-DietShift (less animal products in diet)

NrRB-Combined Constrained by regional $\mathrm{N}$ surplus boundaries with

BAU-Combined
Constrained by regional $\mathrm{N}$ surplus boundaries with a reduction in meat and dairy consumption in regions with above-average consumption by $17 \%, 33 \%$ and $50 \%$ in 2030, 2040 and 2050, respectively, compared with the diet composition under the BAU scenario in the corresponding years. simultaneous implementation of all the above mitigation measures.

Constrained by regional $\mathrm{N}$ surplus boundaries with the gap between D in 2010 and $100 \%$ WWTP connection for and $75 \%$ in 2020, 2030, 2040 and 2050, respectivelyd; regional changes in $\mathrm{N}$ removal rate derived from ref. ${ }^{81 e}$; $50 \%$ of the N removed by WWTPs is recycled as fertilizer that target starting in 2030.

Constrained by regional $\mathrm{N}$ surplus boundaries with a $17 \%$, $33 \%$ and $50 \%$ reduction in harvest loss and food waste in 2030, 2040 and 2050, respectively, compared with harvest loss and food waste under the BAU scenario in the corresponding yearsf.

Simultaneous implementation of all the above mitigation measures without $\mathrm{N}$ surplus constraints. the urban population being closed by $25 \%, 50 \%, 62.5 \%$
Positive: reduces $\mathrm{N}$ air and water pollution (high NUE indicates less $\mathrm{N}$ losses per unit of production); decreases $\mathrm{N}$ fertilizer demand.

Positive: directly reduces $\mathrm{N}$ surplus from livestock systems; effectively reduces direct manure discharge to water bodies; technologies reducing $\mathrm{N}$ loss during manure storage, processing and application could improve local air and water quality and reduce mineral $\mathrm{N}$ fertilizer demand for food and feed production.

Negative: might increase soil $\mathrm{N}_{2} \mathrm{O}$ emissions during manure application to soils.

Positive: decreases direct $\mathrm{N}$ discharge to water bodies; $N$ removed by WWTPs can be recycled to substitute $\mathrm{N}$ fertilizers.
Zhang et al. ${ }^{50}$

Adapted from UNEP $^{79}$ and Kanter et al. ${ }^{80}$

Van Drecht et al. ${ }^{8}$

Positive: lowers total demand (actual food consumption plus food waste); effective supply (production minus losses in field, during

United Nations ${ }^{82}$ and Springmann et al. ${ }^{12}$

processing and during transportation) can effectively satisfy human food intake with less agriculture production; potentially reduces $\mathrm{N}$ fertilizer demand, $\mathrm{N}$ surplus and agricultural GHG emissions for food production.

Positive: improves the health of people who overconsume meat and dairy products; effectively reduces $\mathrm{GHG}$ emissions from

Bodirsky et al. ${ }^{23}$ and Frank et al. ${ }^{32}$

aThe BAU changes in NUE are based on the finding that cropland NUE first decreases and then increases with economic growth (that is, an environmental Kuznets curve) ${ }^{50,83}$. We assume that the cropland and pasture NUE of Organisation for Economic Co-operation and Development (OECD) countries will reach the target NUEs of ref. ${ }^{50}$ by 2050 and that the cropland and pasture NUE of non-OECD countries will converge to a lower target. The low target NUEs by 2050 are set to $0.5,0.4$ and 0.4 for non-OECD countries in Latin America, sub-Saharan Africa and Asia, respectively, which indicate an increasing NUE for countries such as India and China, a decreasing NUE for countries such as Malawi, and a constant NUE for countries such as Brazil. For regions where the baseline NUE (for the year 2010) calculated by the model is higher than the target NUEs of ref. ${ }^{50}$, no NUE changes are applied. ${ }^{\text {In }}$ the model, the share of collected manure (that is, excluding that left on pastures by grazing livestock) allocated to other uses is capped at $10 \%$ by 2050 (adapted from refs. ${ }^{79,80}$ ) with a linear progression towards that target starting in 2010 . ${ }^{c}$ The fraction of $\mathrm{N}$ loss during manure management is assumed to be reduced by $50 \%$ by 2050 through technological improvement of manure management, with a linear progression towards that target starting in 2010 . dThe sewage treatment improvement is adapted from the Global Orchestration scenario ${ }^{81}$ in the Millennium Assessment Scenarios. The scenario assumes $50 \%$ of the gap between D in 2000 and full connection to wastewater treatment plants (WWTPs) for the urban population (that is, $100 \%$ improved sanitation) is closed in the period $2000-2030$, and a further $50 \%$ of the remaining gap is closed in the period $2030-2050$. The increase in $\mathrm{N}$ removal rate follows the regional improvement shown in Table 4 of ref. ${ }^{81}$. ${ }^{\text {TT }}$ The increase in $\mathrm{N}$ removal rate follows the regional improvement shown in Table 4 of ref. ${ }^{81}$. This is a projection in line with pledges made as part of the Sustainable Development Goals ${ }^{12,82}$. GLOBIOM integrates information on the rate of losses and waste on the basis of FAO's past work ${ }^{84}$. It is possible in the model to distinguish domestic food consumption (including waste) from food intake per capita (net excluding waste). Reducing waste therefore allows the demand for food and the pressure on land use and the environment to be decreased without affecting food intake. The model represents such scenarios as 'what if?' assumptions, simply changing the parameter values without any assumption about the underlying cost of such policies. 


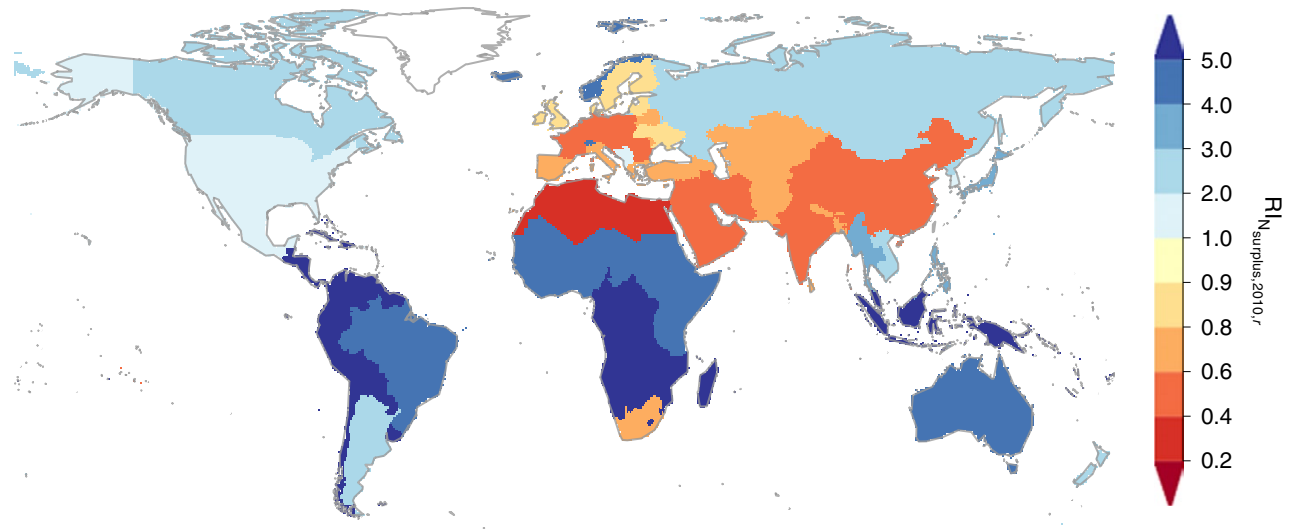

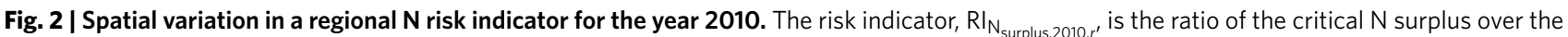
current $\mathrm{N}$ surplus and measures the degree of exceedance of the estimated surface runoff and leaching $\mathrm{N}$ flow in surface water relative to the critical $\mathrm{N}$

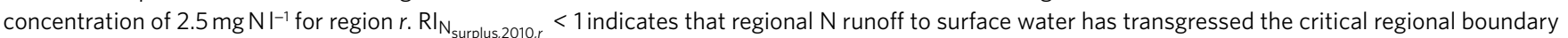

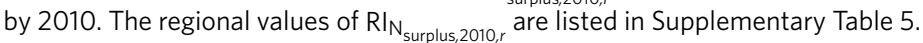

Agricultural production strongly decreases compared with the BAU scenario, and food supply largely relies on agricultural imports in South Asia, eastern Asia, and the Middle East and North Africa (Supplementary Figs. 1 and 2). In the absence of dedicated N-surplus mitigation strategies, international trade acts as the main adjustment mechanism. International trade in crop and animal products compared with the BAU scenario is projected to increase by $36 \%$ and $117 \%$, respectively (Fig. $3 \mathrm{~b}$ ), in spite of the lower global production (Fig. 3a). Food prices are projected to rise very unevenly across regions, reflecting the different levels of the critical regional $\mathrm{N}$ surplus (Supplementary Fig. 1). South Asia sees a strong decrease in dietary energy and protein availability, leading to a large population at risk of hunger ( 495 million) by 2050 under the NrRB-BAU scenario (Fig. 5). The strongest decrease in dietary energy (-19\%) and protein $(-20 \%)$ availability compared with the BAU scenario is projected in eastern Asia by 2050 under the NrRB-BAU scenario (Supplementary Figs. 4 and 5). Eastern Asia and the Middle East and North Africa are projected to have populations at risk of hunger of 94 million and 13 million, respectively, by 2050 under the NrRB-BAU scenario, which are lower values than those in 2010, but still 9.4 times and 2.1 times those projected under the BAU scenario, respectively.

In Southeast Asia, sub-Saharan Africa, and Latin America and the Caribbean, the regional critical $\mathrm{N}$ surplus is much higher than the current level of $\mathrm{N}$ runoff to surface water (Fig. 2), allowing further increases in agricultural production through expansion and/ or intensification. However, this does not prevent a larger population from being projected to be at risk of hunger in Southeast Asia (53 million under the NrRB-BAU scenario compared with 23 million under the BAU scenario) and sub-Saharan Africa (76 million under the NrRB-BAU scenario, compared with 60 million under the BAU scenario). In these two regions, we projected a lower dietary energy and protein intake under the NrRB-BAU scenario than that under the BAU scenario (Supplementary Figs. 4 and 5), in spite of similar or even higher agricultural production (Supplementary Figs. 1 and 2). Similar dynamics are projected for Latin America and the Caribbean, albeit with a smaller impact on hunger.

For the former Soviet Union region, the number of people at risk of hunger remains small. Zero hunger in Europe, North America and Oceania is due to model assumptions that follow the FAO approach (Methods). The level of crop and animal production in North America and Oceania is projected to be even higher under the NrRB-BAU scenario than that under the BAU scenario (Supplementary Figs. 1 and 2), which is explained by two factors: the potential for additional production within regional $\mathrm{N}$ boundaries (that is, the environmental capacity to produce more; $\mathrm{RI}_{\mathrm{N}_{\text {surplus }, r}}>1$ ) and the demand for food imports by regions with stringent $\mathrm{N}$ constraints.

The effects of $\mathbf{N}$ mitigation strategies. Combining all mitigation strategies considered in this study (the NrRB-Combined scenario) can entirely eliminate the negative impacts on food security from constraining regional $\mathrm{N}$ surplus. The combination reduces the population at risk of hunger to 234 million by 2050 , which is 590 million lower than that in 2010, 54 million lower than that under the BAU scenario and 507 million lower than that under the NrRB-BAU scenario. By 2050, food prices would be 19\% lower than in 2010 (that is, $14 \%$ below their 2050 levels under the BAU scenario). The global $\mathrm{N}$ surplus would be reduced to $65 \mathrm{Tg} \mathrm{Nyr}^{-1}$ by 2050 , which is $45 \%$ of the value in $2010\left(144 \mathrm{Tg} \mathrm{Nyr}^{-1}\right)$. The regional $\mathrm{N}$ surplus would still hit the regional boundary in the Middle East and North Africa (that is, food production would still be limited by the critical N surplus; Supplementary Fig. 6). The global N fertilizer demand would be reduced to $35 \mathrm{Tg} \mathrm{Nyr}^{-1}$ by 2050 (35\% of the $\mathrm{N}$ fertilizer use of $100 \mathrm{Tg} \mathrm{Nyr}^{-1}$ in 2010). In addition, combining all strategies to reach regional $\mathrm{N}$ boundaries would provide a large contribution to achieving the goals of the Paris Agreement. While in 2050 the expected reduction of agricultural non- $\mathrm{CO}_{2}\left(\mathrm{CH}_{4}+\mathrm{N}_{2} \mathrm{O}\right)$ emissions in $1.5^{\circ} \mathrm{C}$ target mitigation pathways lies in the range of $2.9-4.9 \mathrm{GtCO}_{2} \mathrm{e} \mathrm{yr}^{-1}$ (ref. ${ }^{32}$ ), the NrRB-Combined scenario reaches in the same year a non- $\mathrm{CO}_{2}$ GHG emissions reduction of $2.3 \mathrm{GtCO}_{2} \mathrm{e} \mathrm{yr}^{-1}$ in comparison with the BAU scenario. This $2.3 \mathrm{GtCO}_{2} \mathrm{e} \mathrm{yr}^{-1}$ consists of $1.0 \mathrm{GtCO}_{2} \mathrm{e} \mathrm{yr}^{-1}$ in $\mathrm{CH}_{4}$ reductions from decreased livestock numbers and $1.3 \mathrm{GtCO}_{2} \mathrm{e} \mathrm{yr}^{-1}$ in $\mathrm{N}_{2} \mathrm{O}$ reductions due to less mineral fertilizer, less manure managed and applied, and a higher NUE (that is, less losses; Fig. 4f). Under the NrRB-Combined scenario, the results on food security indicators, $\mathrm{N}$ surplus, $\mathrm{N}$ fertilizer demand and agricultural non- $\mathrm{CO}_{2}$ emissions are almost the same as those under the BAU-Combined scenario without constraining the regional $\mathrm{N}$ surplus. The only differences came from the Middle East and North Africa, where food security was still slightly limited by the low critical N surplus (Fig. 5b).

Under $\mathrm{N}$ constraints, most individual $\mathrm{N}$ mitigation options considered here can improve global food security by 2050, compared with the NrRB-BAU scenario, by reducing the population at risk of hunger (67 to 420 million less undernourished) and food prices (by $7 \%$ to $26 \%$; Fig. $4 \mathrm{c}$,d). All of these scenarios alleviate global environmental pressure by different magnitudes through decreasing $\mathrm{N}$ surplus (by 0 to $45 \mathrm{Tg} \mathrm{Nyr}^{-1}$; Fig. $4 \mathrm{f}$ ), although the effects on 
a

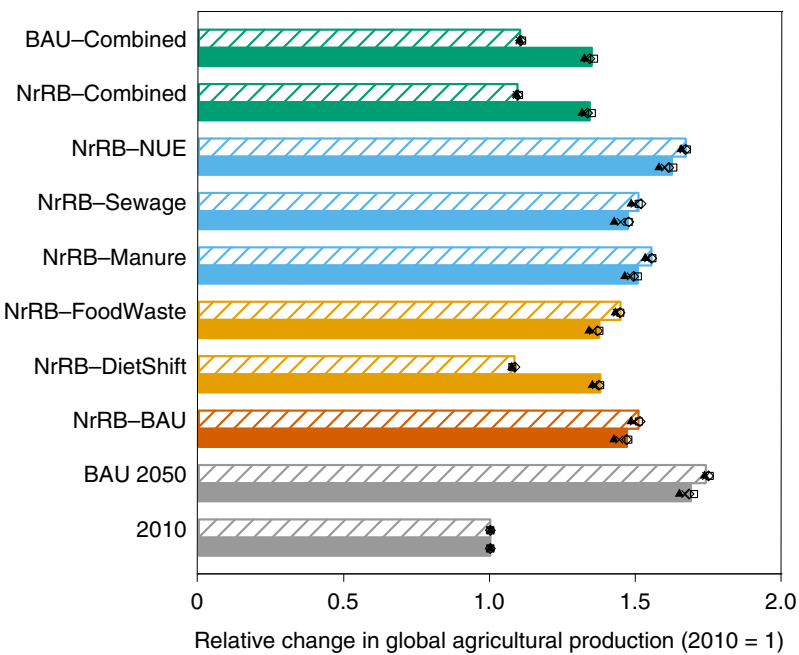

b

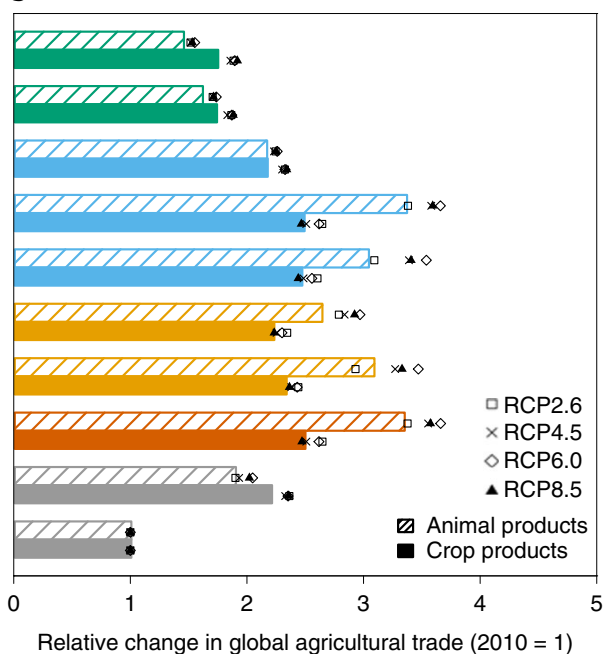

Fig. 3 | Projections of relative changes in global agricultural production and international trade for crop (in dry matter) and animal products (in protein). a, Projections for global agricultural production. b. Projections for international trade. The projections are presented as relative changes compared with the year 2010 under a BAU scenario and under scenarios constrained by regional $\mathrm{N}$ boundaries ( $\mathrm{NrRB}$ ) in combination with BAU, dedicated $\mathrm{N}$ mitigation strategies and a combination of all $\mathrm{N}$ mitigation strategies. The bars indicate the results without assuming climate change impacts, and the symbols indicate the range associated with climate-change-induced crop and grass impacts in line with the 2.6, 4.5, 6.0 and $8.5 \mathrm{~W} \mathrm{~m}{ }^{-2} \mathrm{RCP}$ scenarios. The narratives of the scenarios and the details about the underlying assumptions and data are provided in Table 1.

agricultural non- $\mathrm{CO}_{2}$ GHG emissions can be different in sign depending on the scenario (from $+0.2 \mathrm{GtCO}_{2} \mathrm{e} \mathrm{yr}^{-1}$ to $-0.7 \mathrm{GtCO}_{2} \mathrm{eyr}^{-1}$; Fig. $4 \mathrm{~g}$ ). The individual efforts reduce global $\mathrm{N}$ fertilizer use by 4 to $45 \mathrm{Tg} \mathrm{Nyr}^{-1}$ by 2050 , compared with that under the NrRB-BAU scenario. The impacts of these strategies are even more disparate at the regional level (Supplementary Figs. 1-8).

Reaching targeted high NUE (the NrRB-NUE scenario) is the most effective option considered here to reduce the population at risk of hunger ( -420 million), $\mathrm{N}$ surplus $\left(-45 \mathrm{Tg} \mathrm{Nyr}^{-1}\right.$ ) and $\mathrm{N}$ fertilizer demand $\left(-45 \mathrm{Tg} \mathrm{Nyr}^{-1}\right)$. The scenario substantially increases food production in regions with low limits of $\mathrm{N}$ surplus compared with the NrRB-BAU scenario (that is, the Middle East and North Africa, South Asia, and eastern Asia; Fig. 2) and effectively reduces their population at risk of hunger (Fig. 5).

Improving manure recycling (the NrRB-Manure scenario) directly reduces $\mathrm{N}$ surplus from manure management, thus allowing more $\mathrm{N}$ surplus in cropland and pasture systems given that the total regional $\mathrm{N}$ surplus is constrained, particularly in regions that are already close to or above the critical $\mathrm{N}$ surplus. Compared with the NrRB-BAU scenario, it reduces the population at risk of hunger by 67 million (mainly in China and India).

Improving sewage treatment and recycling (the NrRB-Sewage scenario) does not greatly affect the food security indicators, as it does not change $\mathrm{N}$ surplus over agricultural land. However, it reduces the direct discharge of $\mathrm{N}$ into surface water (point loads). The recycling of removed $\mathrm{N}$ from wastewater treatment plants has a

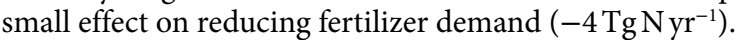

Reducing harvest loss increases the supply without using any additional land or fertilizer. Reducing food waste throughout the supply chain effectively reduces the agricultural production needed to satisfy the human food demand. More people can therefore be fed with less food production, reducing the population at risk of hunger by 224 million compared with the NrRB-BAU scenario. This scenario reduces undernourishment in all regions (Fig. 5).

Changing diets towards less animal products (the NrRB-DietShift scenario) reduces the population at risk of hunger by 208 million compared with the NrRB-BAU scenario. This large reduction is driven by the fact that a plant-based diet makes a meal more affordable as the total system costs of food production are reduced. Given the fact that animal products have low $\mathrm{N}$ efficiency and high GHG emission intensity compared with crop production, less meat and milk consumption can also reduce GHG emissions to 4.2 $\mathrm{GtCO}_{2} \mathrm{e} \mathrm{yr}^{-1}$ (Fig. 4g). A decrease in global $\mathrm{N}$ fertilizer demand $\left(-5 \mathrm{TgNyr}^{-1}\right)$ is projected by 2050 , compared with that under the NrRB-BAU scenario, as a result of two contrasting effects: feed demand reduction from crop-based products and increased mineral $\mathrm{N}$ fertilizer demand due to the reduced availability of manure (caused by lower livestock numbers).

The effects of climate change. Compared with the BAU scenario (not accounting for climate change impacts), price changes in the RCP8.5 scenario (+4\%) lead to reductions in global dietary energy $(-2 \%)$ and protein $(-1 \%)$ availability by 2050 , and an additional 63 million people are projected to become undernourished. Limiting regional $\mathrm{N}$ surplus below a critical boundary is projected to amplify the negative impacts of climate change. Compared with the NrRB-BAU scenario, a 6\% price increase and an additional 117 million undernourished people are projected in the RCP8.5 scenario (Fig. 4d). However, such additional negative impacts from climate change can be alleviated when individual $\mathrm{N}$ mitigation strategies are implemented. When combining all mitigation strategies, climate change only caused an additional 32 million people to be undernourished in the RCP8.5 scenario compared with the NrRB-Combined scenario without climate change (Fig. 4d).

The climate impacts on food security differ among regions. Under the RCP8.5 climate scenario, crop dry matter production is projected to be notably lower than under scenarios without climate change in North America, Southeast Asia, South Asia and sub-Saharan Africa, while Oceania, the former Soviet Union region, Latin America and Europe are projected to benefit from climate change with higher crop production (Supplementary Fig. 1). Through adjustment in trade, supply and demand, a high global warming level under the RCP8.5 climate scenario would lead to higher global food prices and lower dietary energy and protein availability in North America, Southeast Asia, South Asia and sub-Saharan Africa, and would cause additional people to 
a

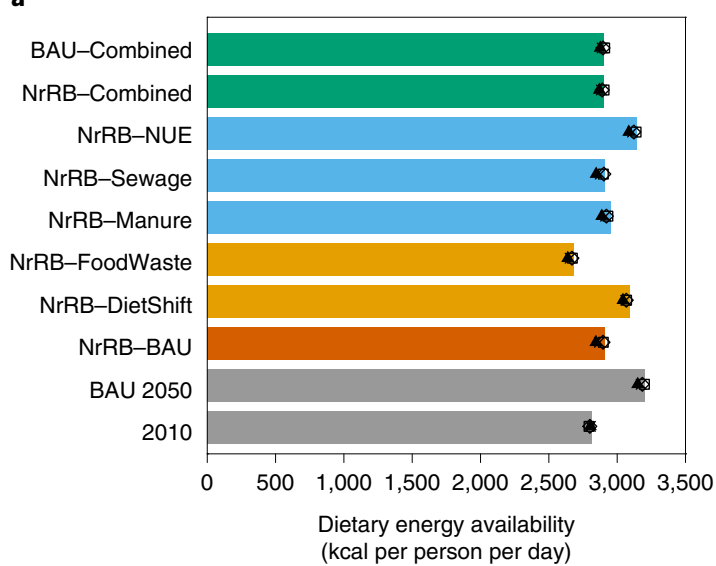

d

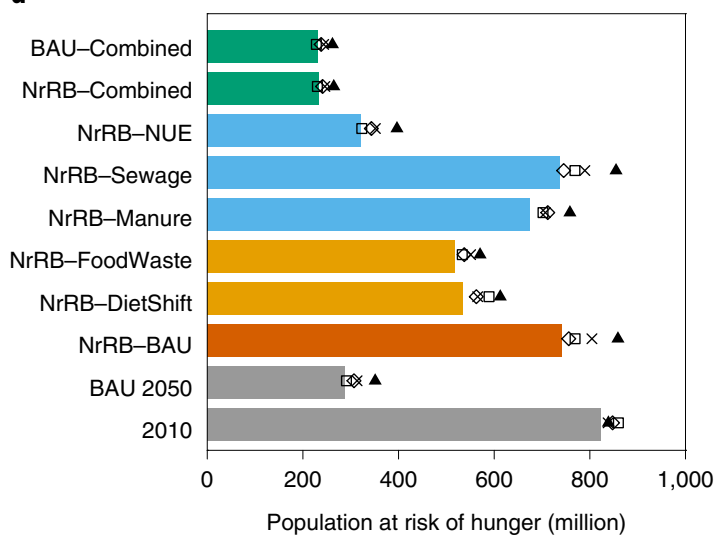

g

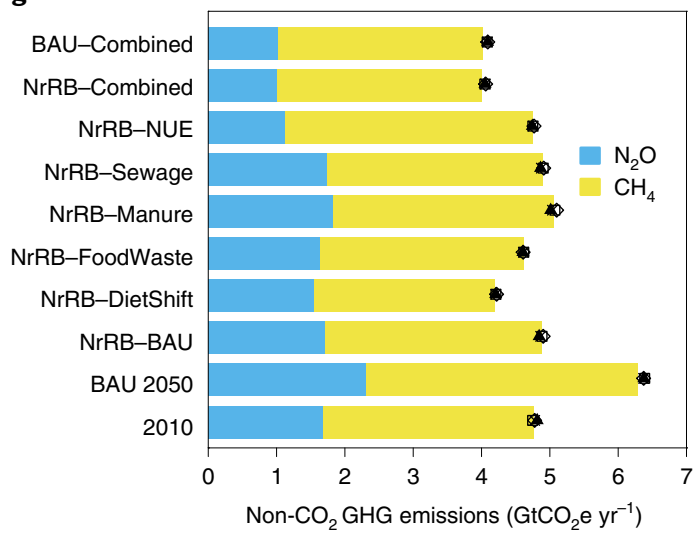

b

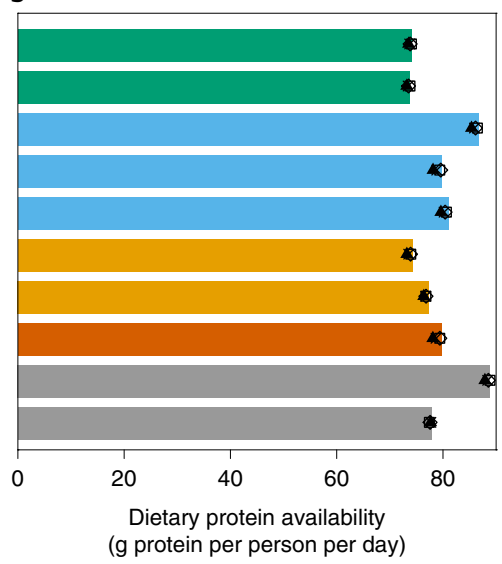

e

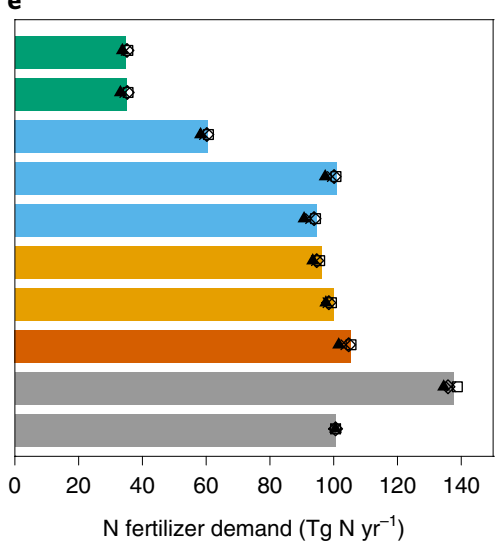

C

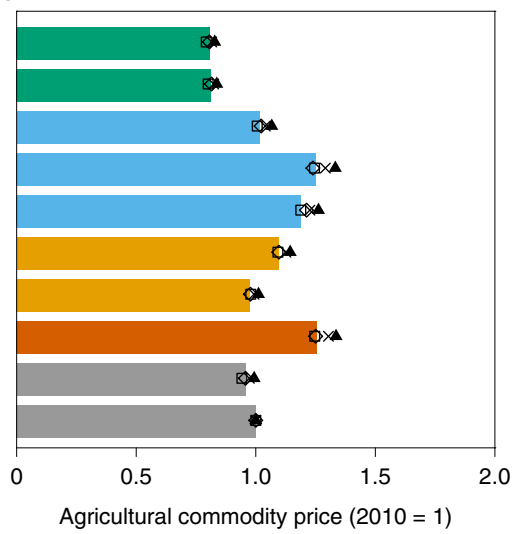

f

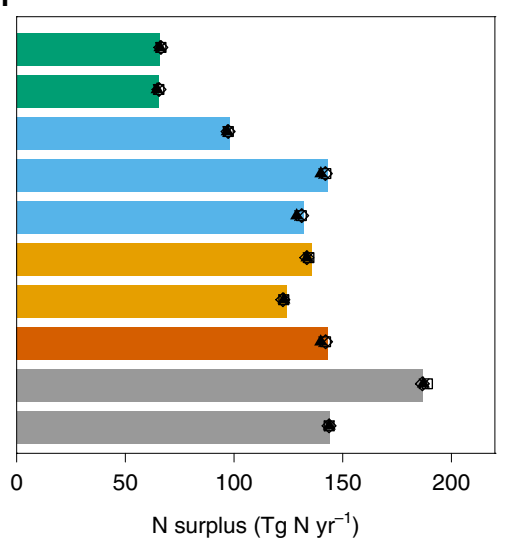

Fig. 4 | Projections of indicators related to food security and associated $\mathbf{N}$ cycles and non- $\mathrm{CO}_{2}$ GHG emissions. a-g, Projections of dietary energy availability (a), dietary protein availability (b), agricultural commodity price index (c), population at risk of hunger (d), mineral $\mathrm{N}$ fertilizer use/demand (e), $\mathrm{N}$ surplus (f) and agricultural non- $\mathrm{CO}_{2}$ GHG emissions (g). Values are presented for the year 2010, a BAU scenario, and scenarios constrained by regional $\mathrm{N}$ boundaries ( $\mathrm{NrRB}$ ) in combination with BAU, dedicated $\mathrm{N}$ mitigation strategies and a combination of all $\mathrm{N}$ mitigation strategies. The value for 2010 in $\mathbf{d}$ refers to mineral $\mathrm{N}$ fertilizer use from data, while the values for 2050 under different scenarios refer to mineral $\mathrm{N}$ fertilizer demand projected by the model. The bars indicate the results without assuming climate change impacts, and the symbols indicate the range associated with climate-change-induced crop and grass impacts in line with the 2.6, 4.5, 6.0 and $8.5 \mathrm{~W} \mathrm{~m}^{-2} \mathrm{RCP}$ scenarios. The narratives of the scenarios and the details about the underlying assumptions and data are provided in Table 1.

become undernourished in South Asia (+50 million), sub-Saharan Africa (+10 million) and Southeast Asia ( +3 million; Fig. 5 and Supplementary Figs. 3-5). Climate change impacts on food security are less pronounced under intermediate climate change (that is, the RCP4.5 and RCP6.0 scenarios) and are marginal under a low global warming level (the RCP2.6 scenario; Fig. $4 \mathrm{a}-\mathrm{d}$ ).

\section{Discussion}

Although our study represents the state of the art in this area, there are some additional aspects of water quality, food security and sustainability dimensions that could be considered. For example, the critical $\mathrm{N}$ surplus and the associated constraints applied in the model are still highly aggregated (37 regions are represented in 
a

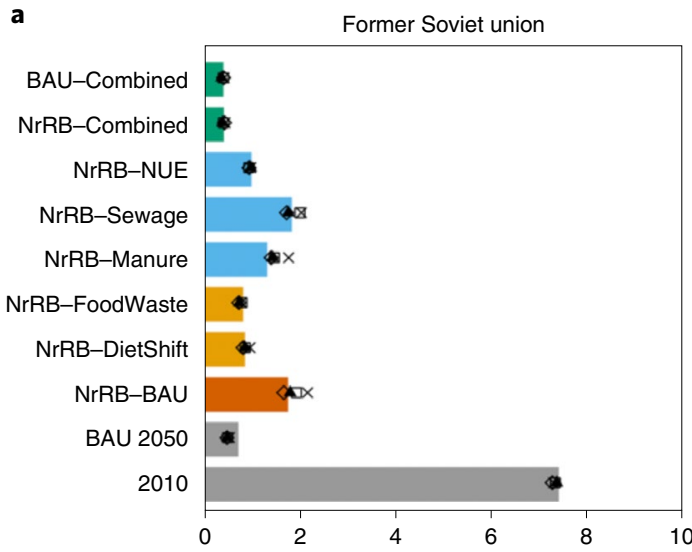

b

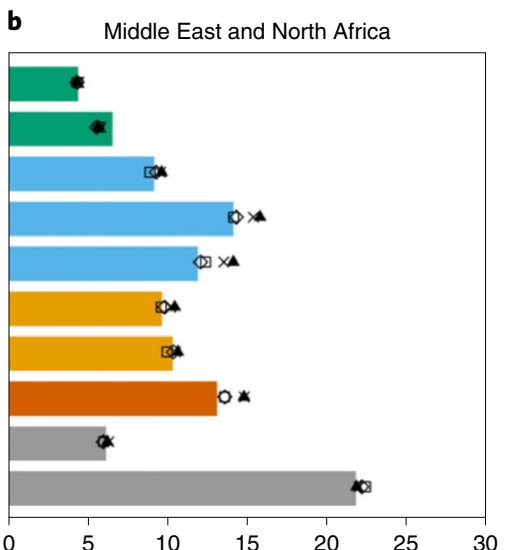

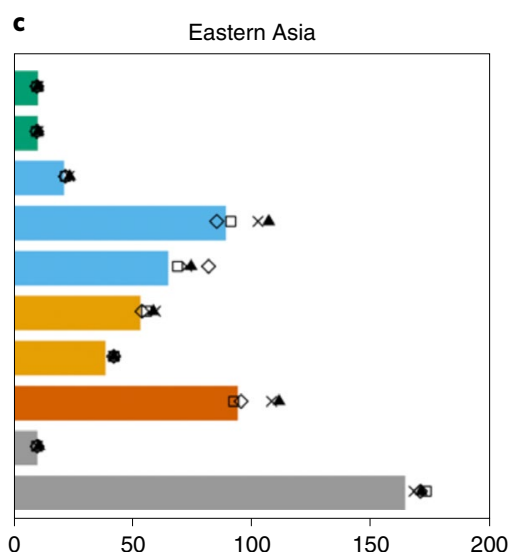

d
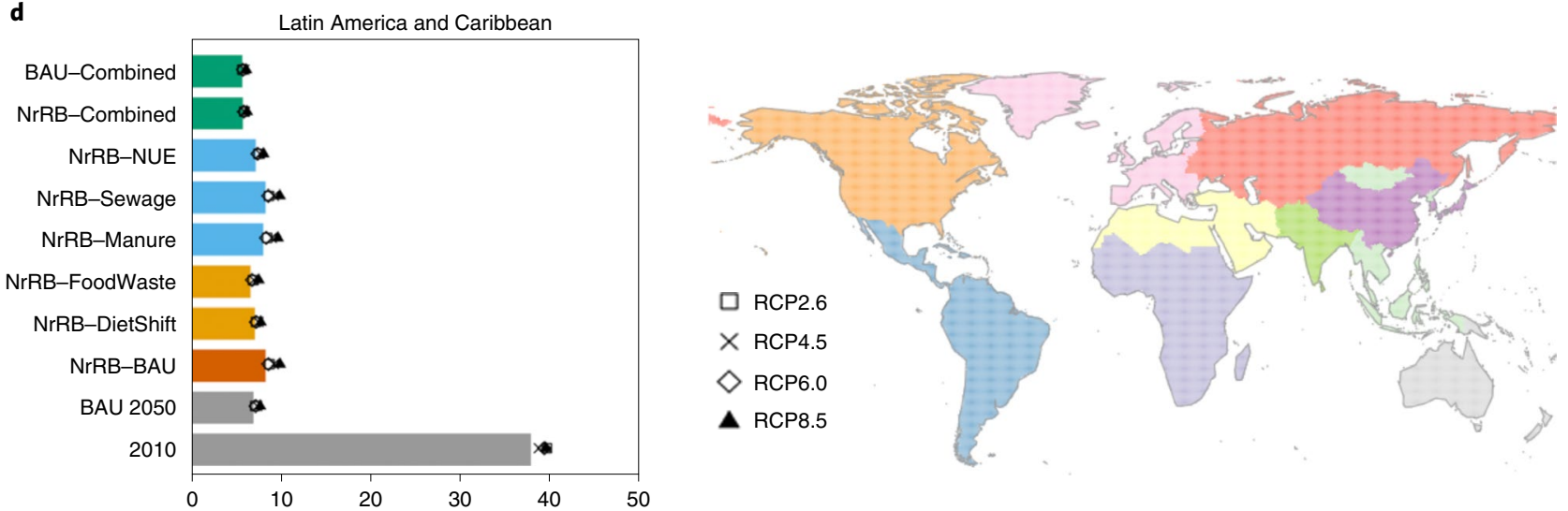

e

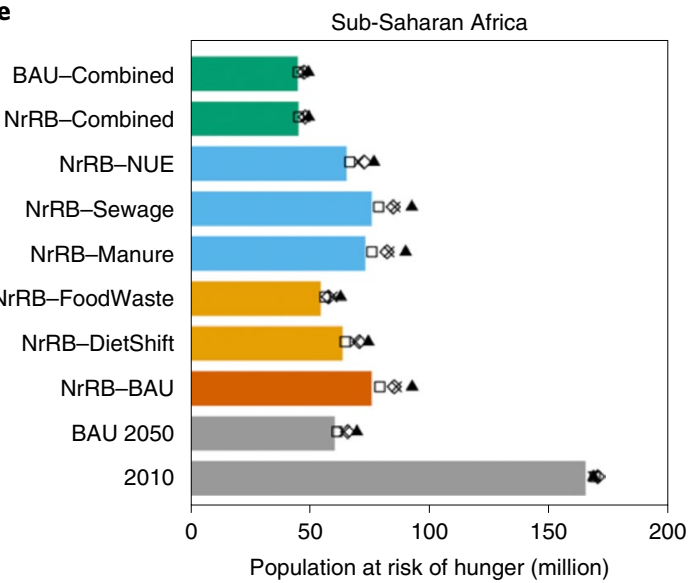

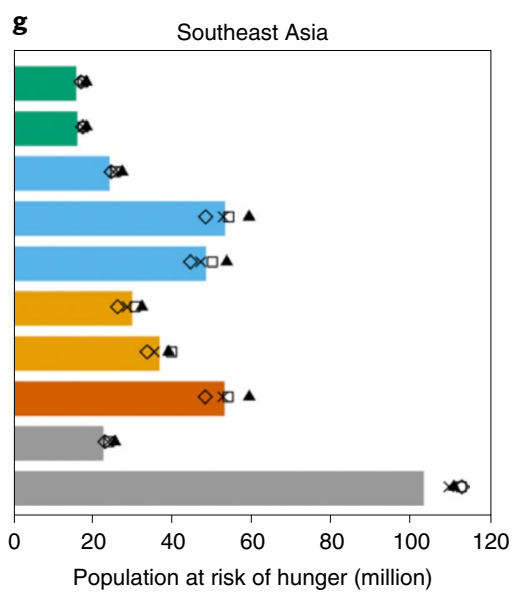

Fig. 5 | Population at risk of hunger by 2050 in selected world regions under different $\mathbf{N}$ management and climate scenarios. a-g, Population at risk of hunger in the former Soviet Union (a), the Middle East and North Africa (b), eastern Asia (c), Latin America and the Caribbean (d), sub-Saharan Africa (e), South Asia (f) and Southeast Asia ( $\mathbf{g}$ ). For developed countries in North America, Europe and Oceania, the population at risk of hunger measure is not applicable because, in accordance with FAO's approach, it was assumed that there was no PoU in these regions ${ }^{74}$. The horizontal scale of the regional population at risk of hunger has been adjusted so that the effects can be easily seen. The figure legend is consistent with those of Figs. 3 and 4.

the model), not allowing for a spatially explicit representation of water pollution. The critical $\mathrm{N}$ concentration may still be exceeded in parts of a region (hot spots of water $\mathrm{N}$ pollution; for example, the northeastern United States and the Mississippi River basin ${ }^{33}$ ). We applied a time-fixed coefficient of variation of the distribution of dietary energy consumption within countries ${ }^{34}$. In fact, pursuing more equitable food distribution by reallocating food deficits and excesses (for example, through reducing overconsumption) is another effective way of reducing food insecurity and environmental impacts ${ }^{35}$. Production and related land expansion in the regions well within the $\mathrm{N}$ boundary could lead to biodiversity loss and carbon emissions from land conversion. These additional trade-offs, which are not explicitly considered here, reinforce the importance of integrated strategies for more sustainable and equitable development. Despite these potential extensions, our study provides a robust assessment of the trade-offs between nitrogen required for ensuring food security and the risk of nitrogen losses causing environmental pollutions, and quantifies how different $\mathrm{N}$ mitigation strategies contribute to reconciling the trade-offs. 
Our analysis indicates that environmental targets of limiting $\mathrm{N}$ surplus require large-scale deployment of dedicated $\mathrm{N}$ mitigation strategies to avoid a strong increase in the risk of food insecurity. Without these measures, the global per capita dietary energy availability would be largely reduced with high levels of food prices and a high undernourished population. This tension between respecting regional nitrogen surplus boundaries and food security would be even larger than that between food security and stringent climate mitigation targets where the population at risk of hunger was projected to reach $280-500$ million and 310-540 million in 2050 under the $2^{\circ} \mathrm{C}$ and $1.5^{\circ} \mathrm{C}$ climate mitigation scenarios, respectively ${ }^{36}$.

Our results further suggest that if efforts to reduce $\mathrm{N}$ surplus in middle-income developing regions (such as South Asia, the Middle East and North Africa, and eastern Asia) were based on reducing domestic supply rather than improving NUE, this could have severe spillover effects on food security in least developed regions such as sub-Saharan Africa and Southeast Asia (that is, these two regions have similar or even higher agricultural production but lower food consumption and more undernourishment under the NrRB-BAU scenarios than under the BAU scenario; Fig. 5 and Supplementary Figs. 1-5). Increased production leads to higher marginal costs of production due to the higher land prices caused by an increased demand for land and because less productive land is being brought into production. An increased marginal cost of production then translates into higher domestic food prices, leading to reduced food consumption. The magnitude of the effect will depend on the sensitivity of the domestic demand to food prices, expressed through the price elasticity of the demand. The latter typically decreases with the level of the income (as shown in a meta-analysis in ref. ${ }^{37}$ ).

Our results further highlight that policies promoting the mobilization of a comprehensive set of nitrogen mitigation options would allow compliance with the proposed nitrogen sustainability boundary without worsening food security across all world regions. This reconciliation is achieved through domestic efforts in both increasing NUE in agriculture (improving NUE and manure recycling) and decreasing demand (shifting towards diets with less animal products, and reducing harvest loss and food waste), combined with adjustments in international trade of agricultural products, the latter being particularly important if not all mitigation options are deployed (Fig. 3b). This underlines the important role of trade in global food security, while the environmental impacts transmitted via markets should also be considered. Furthermore, the $\mathrm{N}$ mitigation strategies not only reduce food insecurity but also have other environmental and economic co-benefits beyond the impacts of $\mathrm{N}$ pollution, such as reducing agricultural GHG emissions, $\mathrm{N}$ fertilizer use and the associated energy consumption of the fertilizer industry ${ }^{38,39}$.

According to our results, increasing NUE is the most effective strategy to reduce undernourishment while respecting the $\mathrm{N}$ boundaries in regions such as China and India. This supply-side effort plays a more important role in alleviating food insecurity than demand-side efforts such as diet shifts and reduced waste when introducing regional $\mathrm{N}$ targets. Policies facilitating and encouraging multiple $\mathrm{N}$ mitigation options need to be implemented simultaneously to deal with $\mathrm{N}$ pollution ${ }^{18}$, but these policies face substantial institutional and technical challenges ${ }^{40}$ (see Supplementary Note 1 for a detailed discussion).

\section{Methods}

Overall methodology. We used the global dynamic land-use model GLOBIOM to assess the risk of food insecurity when meeting $\mathrm{N}$ boundaries and to investigate the effects of various sustainability options. First, we improved GLOBIOM by adding extended representations of the $\mathrm{N}$ cycle in global agricultural systems. The model was then applied under the constraint of meeting the regionally derived $\mathrm{N}$ boundaries given by an acceptable $\mathrm{N}$ surplus based on a critical $\mathrm{N}$ limit in surface water. Our indicators of food security are represented by the dietary energy availability and the dietary protein availability (indicators of food availability) and by the number of people at risk of hunger and food prices (indicators of food access).
GLOBIOM description. GLOBIOM is a global partial equilibrium model allocating land-based activities (that is, management of cropland, livestock systems and forestry) under land availability constraints, to maximize the sum of producer and consumer surpluses ${ }^{26}$. The model relies on a geographically explicit representation of land-based activities at a $0.5^{\circ} \times 0.5^{\circ}$ grid cell resolution. Agricultural production is represented for 18 crops (barley, dry beans, cassava, chick peas, corn, cotton, groundnut, millet, oil palm, potatoes, rapeseed, rice, soybeans, sorghum, sugar cane, sunflower, sweet potatoes and wheat) and seven types of livestock (dairy and other bovines (comprising cattle and buffalos), dairy and other sheep and goats, laying hens and broilers, and pigs), the outputs of which are processed to supply the food, feed and bioenergy markets. Each of the activities is described at the grid cell level through technological parameters provided by a specific biophysical model: EPIC ${ }^{41}$ for crops, EPIC and CENTURY $^{42}$ for grassland, RUMINANT ${ }^{43}$ for livestock, and $\mathrm{G}^{4} \mathrm{M}^{44}$ for forestry. For a detailed description of the model, including the biophysical models, the representations of land-use competition and trade, exogenous scenario drivers and their assumptions, and endogenous model behaviour, see Supplementary Note 2. Our socio-economic narrative is parameterized following SSP2 (ref. ${ }^{30}$ ). It includes quantified assumptions of economic and population developments, energy intensity improvements, energy resources, bioenergy resources and use, technology cost developments, and land-use developments (see Table 1 of ref. ${ }^{30}$ for the details). The detailed quantifications and assumptions in SSP2 on the development of crop yields and input intensity, livestock feed conversion efficiency and productivity growth, as well as food demand and losses and wastes (including their differences from other SSPs), can be found in Sections 2.7 and 4.2 and Table 1 of ref. ${ }^{30}$. How the SSP2 implementation compares with the other SSPs (and how GLOBIOM differs from other integrated assessment models (IAMs)) for demand and yields has been extensively discussed in refs. ${ }^{45-48}$. The model is run in a dynamic, recursive setting with ten-year steps over the 2000-2050 period with outputs such as market variables (including demand, supply, trade and prices) and environmental variables (including land and water use, GHG emissions and sinks, and nitrogen balance). All the agricultural and forestry products and their trade are expressed as biomass flows (in $\mathrm{kg}$ fresh or dry matter). Extensive information about the model can be found in earlier studies ${ }^{26,43,49}$ and at www.globiom.org.

Here, we implemented the $\mathrm{N}$ cycle in global agricultural systems (including cropland, pasture and livestock systems) and in related human food systems in GLOBIOM (Supplementary Note 3). We transformed all relevant biomass flows represented in GLOBIOM into $\mathrm{N}$ flows, and we further accounted for additional $\mathrm{N}$ flows, including crop residues, BNF, manure and fertilizer application, atmospheric deposition, and $\mathrm{N}$ losses through leaching and gaseous emissions of $\mathrm{NH}_{3}, \mathrm{NO}$, $\mathrm{N}_{2} \mathrm{O}$ and $\mathrm{N}_{2}$. Figure 1 illustrates the $\mathrm{N}$ flows implemented. Detailed descriptions of the $\mathrm{N}$ flows, with an overview of the mass-balance equations, are presented in Supplementary Note 3, while the data sources are given in Supplementary Tables $1-4$. For future projections, the model is capable of simulating the production, demand and associated land use (that is, cropland and pasture area) of food, feed and livestock products. Since land-use models such as GLOBIOM do not include a process-based representation of the soil $\mathrm{N}$ cycle, we assumed a long-term balance between soil input and output, where mineralized $\mathrm{N}$ was taken up by plants and fully returned to the soil through plant residues, and there was no net accumulation or loss of the soil $\mathrm{N}$ pool for cropland and pasture in the projections. This is also justifiable from the perspective of sustainable use of agricultural land. All $\mathrm{N}$ flows (other than fertilizer use) can also be simulated. To project the future fertilizer use by cropland and pasture, the regional NUEs for the year 2010 are used as an exogenous scenario parameter, and their future development ( $\mathrm{NUE}_{r, t}$, where $t$ indicates the future period) depends on the scenario storyline. The future $\mathrm{N}$ removal and input flows other than mineral fertilizer application are simulated by the model (for example, yields, BNF, deposition after volatilization and manure recycling), and mineral fertilizer application is then adjusted for cropland and pasture to match the exogenous regional NUE assumptions (that is, $\mathrm{NUE}_{r, t}$ for region $r$ in period $t$; see Supplementary Note 3 for the details).

The historical agricultural N flows from GLOBIOM for the years 2000 and 2010 were checked against those from previous studies and statistics (Supplementary Note 4 and Supplementary Tables 7-9). The global N flows (including mineral $\mathrm{N}$ fertilizer, manure $\mathrm{N}$ application and recycling rates, $\mathrm{BNF}$, atmospheric $\mathrm{N}$ deposition, crop removal and residues, $\mathrm{N}$ surplus, $\mathrm{N}$ excretion, $\mathrm{N}$ gaseous emissions and losses by leaching and runoff) and NUE are comparable to the previous global estimates over cropland ${ }^{50-54}$, agricultural land ${ }^{22}$ and livestock systems ${ }^{55}$. Great progress has occurred over the past few years in terrestrial nitrogen cycle modelling, but important uncertainties prevail, especially with respect to manure (production, management, application and deposition; Supplementary Note 4).

In this study, we account for all major agricultural $\mathrm{CH}_{4}$ and $\mathrm{N}_{2} \mathrm{O}$ emissions, including $\mathrm{CH}_{4}$ from enteric fermentation, manure management and rice cultivation, and $\mathrm{N}_{2} \mathrm{O}$ from cropland, pasture and manure management. For a detailed description of the method used for each emission component, see Supplementary Note 5

Although GLOBIOM is run for 37 regions, we aggregated our results to 10 broad regions to aid clarity on the basis of their geographical closeness and the similarity in economic development within each broad region: eastern Asia, 
Europe, the former Soviet Union, Latin America and the Caribbean, the Middle East and North Africa, North America, Oceania, South Asia, Southeast Asia, and sub-Saharan Africa. A list of the regions used in the analysis and country mapping is shown in Supplementary Table 10.

Uncertainty analysis. To account for the uncertainties due to climate change impacts on crop and grass yields, we ran a series of sensitivity simulations with GLOBIOM. Our choice of climate change scenarios was determined by the ISI-MIP Fast Track Protocol used by crop modellers to calculate crop and grass yield impacts ${ }^{56}$. We used all four RCPs that reflect increasing levels of radiative forcing by 2100 (the $2.6 \mathrm{~W} \mathrm{~m}^{-2}, 4.5 \mathrm{~W} \mathrm{~m}^{-2}, 6 \mathrm{~W} \mathrm{~m}^{-2}$ and $8.5 \mathrm{~W} \mathrm{~m}^{-2}$ scenarios) ${ }^{57}$ as projected by the HadGEM2-ES GCM ${ }^{58}$. RCP2.6 represents climate stabilization at $2{ }^{\circ} \mathrm{C}$, and RCP8.5 represents a temperature range of $2.6-4.8^{\circ} \mathrm{C}\left(\right.$ ref. $\left.{ }^{59}\right)$. The yield impacts are based on simulations from the crop model $\mathrm{EPIC}^{60}$. Each $\mathrm{RCP} \times \mathrm{GCM}$ combination was modelled including $\mathrm{CO}_{2}$ fertilization effects.

Climate change impact simulations are conducted for three management systems: subsistence (also used for the low-input commercial system), high-input and irrigated ${ }^{61}$. The dates of operations such as sowing are adapted to the climate ${ }^{61}$. For oil palm, an average value is used (calculated from the climate change impacts on groundnuts, rice, soybeans and wheat) following the protocol of ref. ${ }^{62}$. The climate change impact on grasslands is captured through shifts in relative productivity calculated for managed grasslands by EPIC. It should be noted that the mean values of climate impact on crop yield are used, but climate variability including extreme events could have more severe impacts, which unfortunately cannot be captured in GLOBIOM and similar models.

The climate impacts on agricultural production and food availability are determined by the biophysical impacts on crop and grass yield and the subsequent adaptations through various mechanisms ${ }^{63}$. Marginal adaptation to climate change, in terms of input level or adjustments of operation dates, is implicit in the crop model results. GLOBIOM models additional mechanisms that can mitigate the effects of climate change on the agricultural sector. In addition to relocating production activities within or across the various regions (that is, through production relocation and international trade) to exploit new comparative advantages between locations and individual production activities, a major adaptation mechanism represented in GLOBIOM is switching between different production systems ${ }^{61}$. In the crop sector, this can take the form of shifting some of the production from the rainfed system to the irrigated system in response to increased droughts. In the livestock sector, it generally involves shifting ruminants from grazing systems to mixed crop-livestock systems or vice versa, changes that can play an important role in the future development of the livestock sector ${ }^{49}$.

Building regional $\mathrm{N}$ surplus boundaries. Boundaries for $\mathrm{N}$ are generally based on the inputs. For example, the $\mathrm{N}$ planetary boundary, or the global critical $\mathrm{N}$ input to agriculture, has been derived on the basis of critical $\mathrm{N}\left(\mathrm{NH}_{3}\right)$ emissions to air (with a critical limit of $1-3 \mu \mathrm{g} \mathrm{m}^{-3}$ in air) and critical $\mathrm{N}$ losses by runoff (through surface runoff and leaching) to surface water (with a critical limit of $1-2.5 \mathrm{mg} \mathrm{N}^{-1}$ in runoff) in view of biodiversity impacts on terrestrial and aquatic ecosystems ${ }^{14}$. In this study, however, regional $\mathrm{N}$ boundaries were derived on the basis of a critical $\mathrm{N}$ concentration in runoff (through surface runoff and leaching $\mathrm{N}$ flow) from agricultural land only. In all regions, this is the most limiting condition-that is, not transgressing it probably leads to acceptable nitrate leaching rates to ground water and ammonia emissions to air (as shown by ref. ${ }^{14}$ ). The same result was also found in a spatially explicit calculation for the European Union ${ }^{64}$. Complying with a critical $\mathrm{N}$ concentration in runoff to surface water has also been used in an $\mathrm{N}$ planetary boundary assessment ${ }^{11}$ and in a regional boundary assessment ${ }^{25}$ Unlike the previous studies, however, we calculated a critical $\mathrm{N}$ surplus instead of a critical $\mathrm{N}$ input. The reason is that this is a near-constant value, as it is based on a critical limit in water multiplied by a water flow (which might only slightly change with climate change) and a runoff fraction, linking the $\mathrm{N}$ surplus to $\mathrm{N}$ runoff (see below). A critical N input, however, is also affected by the NUE, which may strongly change through improved fertilizer management ${ }^{12,64}$. We therefore used a critical $\mathrm{N}$ surplus based on a critical $\mathrm{N}$ limit in surface water only as the boundary. In this study, $\mathrm{N}$ surplus is defined as the difference between $\mathrm{N}$ input and $\mathrm{N}$ removal of the agricultural land, including cropland, pasture and livestock systems. Nitrogen input into cropland and pasture consists of mineral fertilizer application, BNF, atmospheric $\mathrm{N}$ deposition, recycled human sewage and manure. For livestock systems, $\mathrm{N}$ input is feed, while $\mathrm{N}$ removal includes livestock production and manure deposited or applied on agricultural land. Nitrogen losses to air and water (that is, leaching, runoff and gaseous $\mathrm{N}$ emission, including $\mathrm{NH}_{3}$, $\mathrm{N}_{2} \mathrm{O}$ and denitrification $\left(\mathrm{N}_{2}\right.$ and $\mathrm{NO}$ ) emissions) are determined by this surplus (see Supplementary Note 3 for the details).

The range of a critical limit of $1-2.5 \mathrm{mg} \mathrm{N}^{-1}$ in runoff is based on a literature review on the ecological and toxicological effects of inorganic $\mathrm{N}$ pollution ${ }^{65}$, leading to $1 \mathrm{mg} \mathrm{Nl}^{-1}$; but an overview of maximum allowable surface water $\mathrm{N}$ concentrations in national surface water quality standards ${ }^{66}$ and different European objectives for $\mathrm{N}$ compounds lead to a limit near $2.5 \mathrm{mg} \mathrm{Nl}^{-1}$. We used the latter one, considering that even under the upper limit of $2.5 \mathrm{mg} \mathrm{Nl}^{-1}$, the regional critical $\mathrm{N}$ surplus has already been far exceeded in many regions. The projected population at risk of hunger showed in this study is still conservative. Taking a lower limit of
$1 \mathrm{mg} \mathrm{Nl}^{-1}$ would make the trade-off even more pronounced, and we considered this too stringent and not really needed.

In line with De Vries et al. ${ }^{14}$, an RI for the $\mathrm{N}$ surplus in region $r$ for the 37 regions $\left(\mathrm{RI}_{\mathrm{N}}\right.$ ) was calculated as:

$$
\mathrm{RI}_{\mathrm{N}_{\text {surplus }, r}}=\mathrm{N}_{\text {surplus,crit }, r} / \mathrm{N}_{\text {surplus,present }, r}
$$

We calculated regional RIs for the $\mathrm{N}$ surplus on the basis of a critical $\mathrm{N}$ runoff (where $\mathrm{N}$ runoff stands for surface runoff and leaching $\mathrm{N}$ flow) to surface water in each region $r\left(\mathrm{RI}_{\mathrm{N}_{\text {runoff, },}}\right)$, assuming that a fixed fraction $\left(f \mathrm{~N}_{\text {runoff }}\right)$ of agricultural $\mathrm{N}$ surplus (as N input minus $\mathrm{N}$ removal; Supplementary Note 3 ) is lost as N runoff to surface water:

$$
\mathrm{RI}_{\mathrm{N}_{\text {surplus }, r}}=\mathrm{RI}_{\mathrm{N}_{\text {runoff }, r}}
$$

with

$$
\begin{gathered}
\mathrm{RI}_{\mathrm{N}_{\text {runoff }, r}}=\mathrm{N}_{\text {runoff,crit, } r} / \mathrm{N}_{\text {runoff,present }, r} \\
\mathrm{~N}_{\text {runoff,crit, } r}=\mathrm{N}_{\text {surplus,crit, } r} \times f \mathrm{~N}_{\text {runoff }} \\
\mathrm{N}_{\text {runoff,present }, r}=\mathrm{N}_{\text {surplus,present }, r} \times f \mathrm{~N}_{\text {runoff }}
\end{gathered}
$$

where $\mathrm{N}_{\text {runoff,present, } r}$ (unit: $\mathrm{TgN}_{\mathrm{Nr}}^{-1}$ ) includes regional $\mathrm{N}$ losses through surface runoff from cropland $\left(\mathrm{N}_{\text {surface-runoff-crop }}\right)$ and pasture $\left(\mathrm{N}_{\text {surface-runoff-pasture }}\right)$ and leaching from cropland ( $\left.\mathrm{N}_{\text {leaching-crop }}\right)$ and pasture $\left(\mathrm{N}_{\text {leaching-pasture }}\right)$, as well as runoff and leaching during manure management $\left(\mathrm{N}_{\text {leach-MMS }}\right)$. Regional values of the critical $\mathrm{N}$ runoff to surface water in region $r\left(\mathrm{~N}_{\text {runoff,crit, } r}\right)$ were calculated as:

$$
\mathrm{N}_{\text {runoff,crit, } r}=W_{\text {runoff,present, } r} \times[\mathrm{N}]_{\text {runoff,crit, } r}
$$

where $W_{\text {runoff,present, } r}$ (unit: $1,000 \mathrm{~km}^{3}$ ) is the regional runoff to surface water in region $r$, and $[\mathrm{N}]_{\text {runoff,crit }, r}$ is the critical $\mathrm{N}$ concentration in surface water $\left(2.5 \mathrm{mg} \mathrm{Nl}^{-1}\right)$. In this study, 'present' refers to the year 2000 given the data availability on $W_{\text {runoff,present, },}$ (see below).

RI values below 1 imply that the agricultural $\mathrm{N}$ surplus and related $\mathrm{N}$ runoff in those regions should decrease to protect water quality, whereas values above 1 imply that the agricultural $\mathrm{N}$ surplus in those regions could increase (in view of crop $\mathrm{N}$ demand) without affecting water quality. The regional $\mathrm{N}$ surplus boundaries $\left(\mathrm{N}_{\text {surplus,crit } r}\right)$ were derived by GLOBIOM by multiplying the present regional $\mathrm{N}$ surplus of agricultural systems (including surpluses over cropland pasture, and livestock systems; $\mathrm{N}_{\text {surplus,present, } r}$ ) in 2000 (see equations (1) and (2)):

$$
\mathrm{N}_{\text {surplus, crit }, r}=\mathrm{N}_{\text {surplus, present }, r} \times \mathrm{RI}_{\mathrm{N}_{\text {runoff, },}}
$$

Given the fact that we used 2010 as the base year, the risk indicator used refers to 2010 (as shown in Fig. 2):

$$
\mathrm{RI}_{\mathrm{N}_{\text {surplus,2010,r }}}=\mathrm{N}_{\text {surplus, crit }, r} / \mathrm{N}_{\text {surplus,2010, } r}
$$

The above components of regional $\mathrm{N}$ losses through surface runoff and leaching $\left(\mathrm{N}_{\text {runoff,present, } r}\right)$ were estimated by GLOBIOM. $\mathrm{N}_{\text {leach-MMs }}$ was calculated using an emission factor gathered from the RUMINANT model (see the supporting information Section 7 and Tables S17-S21 of ref. ${ }^{43}$ ). $\mathrm{N}_{\text {surface-runoff-crop, }} \mathrm{N}_{\text {surface-runoff-pasture, }}$ $\mathrm{N}_{\text {leaching-crop }}$ and $\mathrm{N}_{\text {leaching-pasture }}$ were calculated using a spatially explicit fraction following the INTEGRATOR-MITERRA approach ${ }^{27,28}$, which is adapted from MITERRA-EUROPE ${ }^{67}$. Details on the methods used are presented in Section 3.6 of Supplementary Note 3. We used the regional precipitation surplus in region $r\left(\mathrm{PS}_{\text {present, } r}\right)$ as a proxy for $W_{\text {runoff,present, } r}$, on the basis of the fact that long-term changes in terrestrial water storage (for example, $-108 \pm 64 \mathrm{~km}^{3} \mathrm{yr}^{-1}$ over the 2003-2013 decade ${ }^{68}$ ) are marginal compared with total river discharge (for example, a climatology value of $37,288 \pm 662 \mathrm{~km}^{3} \mathrm{yr}^{-1}$ using data from various periods between 1961 and 1999; ref. $\left.{ }^{69}\right)$. PS was defined as precipitation $(P)$ minus evapotranspiration $(E)$, taken from the CRU-JRA v.1.1 dataset ${ }^{70}$ and the LandFlux-EVAL dataset ${ }^{71}$, respectively. We calculated both $\mathrm{N}_{\text {runoff present } r}$ and PS for a period around 2000 (1996-2005), as the evapotranspiration data we used were not available after 2005 (see below).

Remote areas were not accounted for as they are either unsuitable for agricultural use (for example, high-latitude boreal forest and tundra regions) or undesirable for agriculture expansion in view of ecosystem and biodiversity protection issues (for example, tropical forests in Amazon and Africa). Grid cells at $1^{\circ}$ resolution that were less than $1 \%$ agricultural land (cropland, pasture and rangeland) were therefore excluded in the calculation of PS. Cropland, pasture and rangeland fractions were derived from the HYDE3.2 dataset ${ }^{72}$ for the year 2000. In addition, grid cells with $\mathrm{PS} \leq 0$ (that is, $E \geq P$ ) were excluded to avoid overestimating $\mathrm{N}_{\text {runoff,present, } r}$. As a result, we derived $\mathrm{N}_{\text {runoff,present }, r}$ and $\mathrm{RI}_{\mathrm{N}_{\text {runoff, },}}$ as shown in Supplementary Table 5.

The regional critical $\mathrm{N}$ surplus defined in this way reflects the boundary in view of critical $\mathrm{N}$ concentrations in runoff from agricultural land to surface water. 
Note that the use of a limit value for runoff from agriculture is only a surrogate in terms of the surface water quality ${ }^{64}$. As explained in ref. ${ }^{64}$, higher values can be acceptable due to denitrification or $\mathrm{N}$ retention in surface water, while lower values may be needed because of mixing of runoff water with point loads of $\mathrm{N}$ into surface water. Here, these effects were assumed to compensate for each other, as in ref. ${ }^{64}$. In addition, the regional critical $\mathrm{N}$ surplus is defined at the scale of the whole region and does not reflect the critical $\mathrm{N}$ boundary in individual river basins.

Constraining $\mathrm{N}$ surplus and the impact chain on food security. The regional constraint of a critical $\mathrm{N}$ surplus was included in GLOBIOM by the following function:

$$
\mathrm{N}_{\text {surplus-crop, } r}+\mathrm{N}_{\text {surplus-pasture, } r}+\mathrm{N}_{\text {surplus-live, } r} \leq \mathrm{N}_{\text {surplus, crit }, r}
$$

where $\mathrm{N}_{\text {surplus-crop }, r} \mathrm{~N}_{\text {surplus-pasture } r}$ and $\mathrm{N}_{\text {surplus-live, } r}$ are $\mathrm{N}$ surplus over cropland, pasture and livestock systems in economic region $r$. Regional $\mathrm{N}$ surplus constraints were applied in the model from 2030 to 2050, with linear reduction from the modelled regional N surplus in 2020 under the BAU scenario to $\mathrm{N}_{\text {surplus,crit, } r}$ by 2050 . For North Africa, the $\mathrm{N}$ surplus from other crops (besides the 18 crops modelled explicitly by GLOBIOM) in $2050\left(1.1 \mathrm{Tg} \mathrm{Nyr}^{-1}\right)$ is higher than the $\mathrm{N}_{\text {surplus,crit, } r}$ of $0.75 \mathrm{Tg} \mathrm{Nyr}^{-1}$ (Supplementary Table 5). Since other crop production is considered constant, and the nitrogen use thus cannot be endogenously reduced to comply with the constraint, a value for $\mathrm{N}_{\text {surplus,crit, } r}$ of $1.1 \mathrm{Tg} \mathrm{Nyr}^{-1}$ was used in this region to avoid model infeasibility caused by the total $\mathrm{N}$ surplus constraint.

In all $\mathrm{NrRB}$ scenarios, the regional $\mathrm{N}$ surplus boundaries are used as an additional constraint when solving the model, preventing an overuse of $\mathrm{N}$ in production. Within a region, we assume the same NUE for a given crop and pasture independent of its location and management system, leading to a linear relationship between nitrogen application to a specific crop and its production at the regional level. Hence, for regions where total agricultural $\mathrm{N}$ surplus exceeds the defined regional boundaries and without the dedicated $\mathrm{N}$ mitigation strategies considered in the corresponding $\mathrm{NrRB}$ scenarios, the reduction of $\mathrm{N}$ input to a crop will lead to a proportional decrease in its production, which in turn will lead to increasing food prices. The increase in prices will also trigger several endogenous adjustment mechanisms to adapt to the regional $\mathrm{N}$ constraint: (1) switch between livestock systems if that allows the total surplus from cropland, pasture and livestock to be reduced; (2) supplement the missing domestic supply by imports from regions where the regional $\mathrm{N}$ surplus constraint is not binding; or (3) modify consumption patterns and overall food and feed demand (that is, reduce the mean dietary energy availability). The livestock sector (represented in several alternative production systems) can contribute by adapting feed ratios as well as manure management systems and thus the overall $\mathrm{N}$ efficiency. In regions where total agricultural $\mathrm{N}$ surplus is below the defined regional critical boundaries, production can be increased for exports to satisfy the import demand in the $\mathrm{N}$-constrained regions. Increasing production will also lead to increasing marginal production costs in these regions, which will lead to food price increases and food consumption reduction, although these regions are not locally constrained by their regional $\mathrm{N}$ boundary.

The above-mentioned endogenous model adjustments to the $\mathrm{N}$ surplus constraints will vary on the basis of additional scenario assumptions. For example, with the implementation of one or multiple sustainability efforts, the $\mathrm{N}$ surplus per unit of production can be reduced, allowing for higher domestic production within the defined $\mathrm{N}$ boundaries. Conversely, reduced demand through dietary changes and reduced food waste will facilitate compliance with the $\mathrm{N}$ boundaries and will reduce the pressure on the food system. Lower demand for $\mathrm{N}$-intensive commodities in regions with excessive consumption and higher domestic supply will lead to reduced food prices, which in turn will allow for increased consumption and reduced food insecurity in food-deficient regions.

Estimation of the number of people at risk of hunger. The narrow definition of undernourishment, or hunger, is a state of energy (calorie) deprivation lasting for more than one year; this does not include the short-term effects of temporary crises ${ }^{73}$. The method used to estimate the number of people at risk of hunger is based on the FAO approach ${ }^{74}$. The approach has been implemented in agricultural economic model $\mathrm{s}^{75,76}$ and has recently been applied in eight global agricultural economic models (including GLOBIOM) to assess the risk of food insecurity ${ }^{34}$. In principle, the risk of hunger is calculated by referring to the mean dietary energy availability projected by GLOBIOM (specific to the scenario and time horizon). The population at risk of hunger is a multiple of the prevalence of undernourishment (PoU) and the total population. According to $\mathrm{FAO}^{74}$, the PoU is calculated from three key factors: the mean dietary energy availability (kcal per person per day), the mean minimum dietary energy requirement (MDER, time-fixed in this study) and the coefficient of variation of the domestic distribution of dietary energy consumption in a country. The food distribution within a country is assumed to obey a log-normal distribution, which is determined by the mean dietary energy availability (mean) and the equity of the food distribution (variance) ${ }^{34}$. The proportion of the population under the MDER is then defined as the PoU. The calorie-based food consumption (kcal per person per day) output from GLOBIOM was used as the mean dietary energy availability.
The future mean MDER is calculated for each year and country using the mean MDER in the base year at the country level ${ }^{29}$ and an adjustment coefficient for the MDER in different age and sex groups ${ }^{77}$ and the future population demographics ${ }^{78}$ to reflect differences in the MDER across age and sex. The future equality of food distribution was estimated by applying the historical trend of income growth and the improved coefficient of variation of the food distribution to the future, so that equity is improved along with income growth in the future at an historical rate up to the present best value (0.2). Here, we took into account the increased food availability for intake, in the case where food waste is reduced (as in the NrRB-FoodWaste scenario), by introducing an extra parameter for domestic food waste to be applied to dietary energy availability. Currently, according to the FAO approach, there is assumed to be no PoU in Europe, North America and Oceania, and so the PoU measure is not applicable in these three regions (see ref. ${ }^{75}$ for more information).

Reporting Summary. Further information on research design is available in the Nature Research Reporting Summary linked to this article.

\section{Data availability}

The main data that support the findings of this study are available at the public Data Repository of the International Institute of Applied Systems Analysis (https:// dare.iiasa.ac.at/125/ and https://doi.org/10.22022/IBF/07-2021.125). Source data are provided with this paper.

\section{Code availability}

The code used for the statistical analysis of the scenario data is available from the corresponding author on request.

Received: 23 September 2020; Accepted: 16 August 2021; Published online: 13 September 2021

\section{References}

1. Sutton, M. A. et al. Our Nutrient World: The Challenge to Produce More Food and Energy with Less Pollution (Centre for Ecology and Hydrology, 2013).

2. Cohen, A. J. et al. Estimates and 25-year trends of the global burden of disease attributable to ambient air pollution: an analysis of data from the Global Burden of Diseases Study 2015. Lancet 389, 1907-1918 (2017).

3. Review of Evidence on Health Aspects of Air Pollution-REVIHAAP Project (WHO, 2013).

4. Cape, J. N., van der Eerden, L. J., Sheppard, L. J., Leith, I. D. \& Sutton, M. A. Evidence for changing the critical level for ammonia. Environ. Pollut. 157, 1033-1037 (2009).

5. Tian, H. et al. Global soil nitrous oxide emissions since the preindustrial era estimated by an ensemble of terrestrial biosphere models: magnitude, attribution, and uncertainty. Glob. Change Biol. 25, 640-659 (2019).

6. Rabalais, N. N., Turner, R. E., Díaz, R. J. \& Justić, D. Global change and eutrophication of coastal waters. ICES J. Mar. Sci. 66, 1528-1537 (2009).

7. Smith, V. H. \& Schindler, D. W. Eutrophication science: where do we go from here? Trends Ecol. Evol. 24, 201-207 (2009).

8. van Grinsven, H. J. M., Rabl, A. \& de Kok, T. M. Estimation of incidence and social cost of colon cancer due to nitrate in drinking water in the EU: a tentative cost-benefit assessment. Environ. Health 9, 58 (2010).

9. Seitzinger, S. P. et al. Global river nutrient export: a scenario analysis of past and future trends. Glob. Biogeochem. Cycles https://doi.org/10.1029/2009gb 003587 (2010)

10. Rockström, J. et al. A safe operating space for humanity. Nature 461, 472 (2009).

11. Steffen, W. et al. Planetary boundaries: guiding human development on a changing planet. Science 347, 1259855 (2015).

12. Springmann, M. et al. Options for keeping the food system within environmental limits. Nature 562, 519-525 (2018).

13. Hillebrand, $H$. et al. Thresholds for ecological responses to global change do not emerge from empirical data. Nat. Ecol. Evol. 4, 1502-1509 (2020).

14. De Vries, W., Kros, J., Kroeze, C. \& Seitzinger, S. P. Assessing planetary and regional nitrogen boundaries related to food security and adverse environmental impacts. Curr. Opin. Environ. Sustain. 5, 392-402 (2013).

15. Lewis, S. We must set planetary boundaries wisely. Nature 485, 417 (2012).

16. Sutton, M. A. et al. The European Nitrogen Assessment: Sources, Effects and Policy Perspectives (Cambridge Univ. Press, 2011).

17. $\mathrm{Yu}, \mathrm{C}$. et al. Managing nitrogen to restore water quality in China. Nature 567, 516-520 (2019).

18. Kanter, D. R., Chodos, O., Nordland, O., Rutigliano, M. \& Winiwarter, W. Gaps and opportunities in nitrogen pollution policies around the world. Nat. Sustain. 3, 956-963 (2020).

19. Sinha, E., Michalak, A. M., Calvin, K. V. \& Lawrence, P. J. Societal decisions about climate mitigation will have dramatic impacts on eutrophication in the 21st century. Nat. Commun. 10, 939 (2019). 
20. Gu, B., Ju, X., Chang, J., Ge, Y. \& Vitousek, P. M. Integrated reactive nitrogen budgets and future trends in China. Proc. Natl Acad. Sci. USA 112, 8792-8797 (2015).

21. Tilman, D., Balzer, C., Hill, J. \& Befort, B. L. Global food demand and the sustainable intensification of agriculture. Proc. Natl Acad. Sci. USA 108, 20260-20264 (2011)

22. Bouwman, L. et al. Exploring global changes in nitrogen and phosphorus cycles in agriculture induced by livestock production over the 1900-2050 period. Proc. Natl Acad. Sci. USA 110, 20882-20887 (2013).

23. Bodirsky, B. L. et al. Reactive nitrogen requirements to feed the world in 2050 and potential to mitigate nitrogen pollution. Nat. Commun. $\mathbf{5}$, 3858 (2014).

24. Folberth, C. et al. The global cropland-sparing potential of high-yield farming. Nat. Sustain. 3, 281-289 (2020).

25. Gerten, D. et al. Feeding ten billion people is possible within four terrestrial planetary boundaries. Nat. Sustain. 3, 200-208 (2020).

26. Havlík, P. et al. Global land-use implications of first and second generation biofuel targets. Energy Policy 39, 5690-5702 (2011).

27. Kros, J. et al. Uncertainties in model predictions of nitrogen fluxes from agro-ecosystems in Europe. Biogeosciences 9, 4573-4588 (2012).

28. De Vries, W. et al. Comparison of land nitrogen budgets for European agriculture by various modeling approaches. Environ. Pollut. 159, 3254-3268 (2011).

29. Food Security Indicators (FAO, 2016); http://www.fao.org/economic/ess/ess-fs/ ess-fadata/en/\#.XdcGvjK2lp-

30. Fricko, O. et al. The marker quantification of the Shared Socioeconomic Pathway 2: a middle-of-the-road scenario for the 21st century. Glob. Environ. Change 42, 251-267 (2017).

31. Elleby, C., Domínguez, I. P., Adenauer, M. \& Genovese, G. Impacts of the COVID-19 pandemic on the global agricultural markets. Environ. Resour Econ. 76, 1067-1079 (2020).

32. Frank, S. et al. Agricultural non- $\mathrm{CO}_{2}$ emission reduction potential in the context of the $1.5^{\circ} \mathrm{C}$ target. Nat. Clim. Change 9, 66-72 (2019).

33. Alexander, R. B. et al. Differences in phosphorus and nitrogen delivery to the Gulf of Mexico from the Mississippi River basin. Environ. Sci. Technol. 42, 822-830 (2008).

34. Hasegawa, T. et al. Risk of increased food insecurity under stringent global climate change mitigation policy. Nat. Clim. Change 8, 699-703 (2018).

35. Hasegawa, T., Havlík, P., Frank, S., Palazzo, A. \& Valin, H. Tackling food consumption inequality to fight hunger without pressuring the environment. Nat. Sustain. 2, 826-833 (2019).

36. Fujimori, S. et al. A multi-model assessment of food security implications of climate change mitigation. Nat. Sustain. 2, 386-396 (2019).

37. Femenia, F. A Meta-analysis of the Price and Income Elasticities of Food Demand Working Paper SMART-LERECO No. 19-03 (INRAE, 2019).

38. The Fertilizer Industry, World Food Supplies and the Environment (IFA, UNEP, 1998).

39. Ammonia Production: Moving Towards Maximum Efficiency and Lower GHG Emissions (IFA, 2014); https://www.fertilizer.org/images/Library_Downloads/ 2014_ifa_ff_ammonia_emissions_july.pdf

40. Houlton, B. Z. et al. A world of cobenefits: solving the global nitrogen challenge. Earth's Future 7, 865-872 (2019).

41. Balkovič, J. et al. Global wheat production potentials and management flexibility under the representative concentration pathways. Glob. Planet Change 122, 107-121 (2014).

42. Parton, W. J. et al. Observations and modeling of biomass and soil organic matter dynamics for the grassland biome worldwide. Glob. Biogeochem. Cycles 7, 785-809 (1993)

43. Herrero, M. et al. Biomass use, production, feed efficiencies, and greenhouse gas emissions from global livestock systems. Proc. Natl Acad. Sci. USA 110, 20888-20893 (2013)

44. Kindermann, G. et al. Global cost estimates of reducing carbon emissions through avoided deforestation. Proc. Natl Acad. Sci. USA 105 10302-10307 (2008).

45. Leclère, D. et al. Bending the curve of terrestrial biodiversity needs an integrated strategy. Nature 585, 551-556 (2020).

46. Popp, A. et al. Land-use futures in the shared socio-economic pathways. Glob. Environ. Change 42, 331-345 (2017).

47. Stehfest, E. et al. Key determinants of global land-use projections. Nat. Commun. 10, 2166 (2019).

48. Valin, H. et al. The future of food demand: understanding differences in global economic models. Agric. Econ. 45, 51-67 (2014)

49. Havlík, P. et al. Climate change mitigation through livestock system transitions. Proc. Natl Acad. Sci. USA 111, 3709-3714 (2014).

50. Zhang, X. et al. Managing nitrogen for sustainable development. Nature 528, 51-59 (2015)

51. Smil, V. Nitrogen in crop production: an account of global flows. Glob. Biogeochem. Cycles 13, 647-662 (1999).
52. Sheldrick, W. F., Syers, J. K. \& Lingard, J. A conceptual model for conducting nutrient audits at national, regional, and global scales. Nutr. Cycling Agroecosyst. 62, 61-72 (2002).

53. Liu, J. et al. A high-resolution assessment on global nitrogen flows in cropland. Proc. Natl Acad. Sci. USA 107, 8035-8040 (2010).

54. Bodirsky, B. L. et al. $\mathrm{N}_{2} \mathrm{O}$ emissions from the global agricultural nitrogen cycle-current state and future scenarios. Biogeosciences 9, 4169-4197 (2012)

55. Uwizeye, A. et al. Nitrogen emissions along global livestock supply chains. Nat. Food 1, 437-446 (2020)

56. Rosenzweig, C. et al. Assessing agricultural risks of climate change in the 21st century in a global gridded crop model intercomparison. Proc. Natl Acad. Sci. USA 111, 3268-3273 (2014).

57. van Vuuren, D. P. et al. The representative concentration pathways: an overview. Climatic Change 109, 5 (2011).

58. Collins, W. J. et al. Development and evaluation of an Earth-system model-HadGEM2. Geosci. Model Dev. 4, 1051-1075 (2011).

59. IPCC Climate Change 2014: Synthesis Report (eds Core Writing Team, Pachauri, R. K. \& Meyer, L. A.) (IPCC, 2014).

60. Leclère, D. et al. Climate change induced transformations of agricultural systems: insights from a global model. Environ. Res. Lett. 9, 124018 (2014).

61. Havlík, P. et al. in Climate Change and Food Systems: Global Assessments and Implications for Food Security and Trade (ed. Elbehri, A.) 177-208 (FAO, 2015).

62. Müller, C. \& Robertson, R. D. Projecting future crop productivity for global economic modeling. Agric. Econ. 45, 37-50 (2014).

63. Nelson, G. C. et al. Climate change effects on agriculture: economic responses to biophysical shocks. Proc. Natl Acad. Sci. USA 111, 3274-3279 (2014).

64. De Vries, W. \& Schulte-Uebbing, L. Required changes in nitrogen inputs and nitrogen use efficiencies to reconcile agricultural productivity with water and air quality objectives in the EU-27. In Proc. 842 of the International Fertiliser Society 1-39 (nternational Fertiliser Society, Cambridge, 2020).

65. Camargo, J. A. \& Alonso, Á. Ecological and toxicological effects of inorganic nitrogen pollution in aquatic ecosystems: a global assessment. Environ. Int. 32, 831-849 (2006).

66. Laane, R. W. P. M. Applying the critical load concept to the nitrogen load of the river Rhine to the Dutch coastal zone. Estuar. Coast. Shelf Sci. 62, 487-493 (2005)

67. Velthof, G. L. et al. Integrated assessment of nitrogen losses from agriculture in EU-27 using MITERRA-EUROPE. J. Environ. Qual. 38, 402-417 (2009).

68. Dieng, H. B. et al. Total land water storage change over 2003-2013 estimated from a global mass budget approach. Environ. Res. Lett. 10, 124010 (2015).

69. Dai, A. \& Trenberth, K. E. Estimates of freshwater discharge from continents: latitudinal and seasonal variations. J. Hydrometeorol. 3, 660-687 (2002).

70. Harris, I. C. CRU JRA v1. 1: A Forcings Dataset of Gridded Land Surface Blend of Climatic Research Unit (CRU) and Japanese Reanalysis (JRA) Data 2905th edn, Vol. 2905 (University of East Anglia Climatic Research Unit Centre for Environmental Data Analysis, 2019).

71. Mueller, B. et al. Benchmark products for land evapotranspiration: LandFluxEVAL multi-data set synthesis. Hydrol. Earth Syst. Sci. 17, 3707-3720 (2013).

72. Klein Goldewijk, K., Beusen, A., Doelman, J. \& Stehfest, E. Anthropogenic land use estimates for the Holocene-HYDE 3.2. Earth Syst. Sci. Data 9 927 (2017).

73. FAO, IFAD, UNICEF, WFP \& WHO The State of Food Security and Nutrition in the World 2019: Safeguarding Against Economic Slowdowns and Downturns (FAO, 2019).

74. Methodology for the Measurement of Food Deprivation: Updating the Minimum Dietary Energy Requirements (FAO, 2008).

75. Hasegawa, T., Fujimori, S., Takahashi, K. \& Masui, T. Scenarios for the risk of hunger in the twenty-first century using Shared Socioeconomic Pathways. Environ. Res. Lett. 10, 014010 (2015).

76. Hasegawa, T. et al. Consequence of climate mitigation on the risk of hunger. Environ. Sci. Technol. 49, 7245-7253 (2015).

77. Energy and Protein Requirements: Report of a Joint FAO/WHO Ad Hoc Expert Committee World Health Organization Technical Report Series No. 522; FAO Nutrition Meetings Report Series No. 52 (WHO, FAO, 1973).

78. Kc, S. \& Lutz, W. The human core of the shared socioeconomic pathways: population scenarios by age, sex and level of education for all countries to 2100. Glob. Environ. Change 42, 181-192 (2017).

79. Drawing Down $\mathrm{N}_{2} \mathrm{O}$ to Protect Climate and the Ozone Layer: A UNEP Synthesis Report (United Nations Environment Programme, 2013).

80. Kanter, D. R. et al. A framework for nitrogen futures in the shared socioeconomic pathways. Glob. Environ. Change 61, 102029 (2020).

81. Van Drecht, G., Bouwman, A. F., Harrison, J. \& Knoop, J. M. Global nitrogen and phosphate in urban wastewater for the period 1970 to 2050. Glob. Biogeochem. Cycles https://doi.org/10.1029/2009gb003458 (2009).

82. Transforming Our World: the 2030 Agenda for Sustainable Development (United Nations, 2015).

83. Lassaletta, L., Billen, G., Grizzetti, B., Anglade, J. \& Garnier, J. 50 year trends in nitrogen use efficiency of world cropping systems: the relationship between yield and nitrogen input to cropland. Environ. Res. Lett. 9, 105011 (2014). 
84. Gustavsson, J., Cederberg, C., Sonesson, U., Van Otterdijk, R. \& Meybeck, A. Global Food Losses and Food Waste - Extent, Causes and Prevention (FAO, 2011).

\section{Acknowledgements}

J.C. and M.O. were supported by European Research Council Synergy grant no. ERC2013-SynG-610028 Imbalance-P. Support from the Global Environment Facility of the United Nations Environment Programme through the project 'Towards an International Nitrogen Management System' for the organization of workshops proved essential to the success of this work.

\section{Author contributions}

J.C. and P.H. designed the study. J.C. carried out the GLOBIOM modelling with help from P.H., D.L., H.V. and A.D. W.d.V. provided the methodology for estimating regional $\mathrm{N}$ surplus boundaries. J.C. performed the analysis and wrote an initial draft. All authors contributed substantially to the interpretation of the results and to the text.

\section{Competing interests}

The authors declare no competing interests.

\section{Additional information}

Supplementary information The online version contains supplementary material available at https://doi.org/10.1038/s43016-021-00366-x.

Correspondence and requests for materials should be addressed to Jinfeng Chang.

Peer review information Nature Food thanks Thomas Nesme, Aimable Uwizeye and the other, anonymous, reviewer(s) for their contribution to the peer review of this work.

Reprints and permissions information is available at www.nature.com/reprints.

Publisher's note Springer Nature remains neutral with regard to jurisdictional claims in published maps and institutional affiliations.

(c) The Author(s), under exclusive licence to Springer Nature Limited 2021, corrected publication 2022 


\section{Reporting Summary}

Nature Research wishes to improve the reproducibility of the work that we publish. This form provides structure for consistency and transparency in reporting. For further information on Nature Research policies, see our Editorial Policies and the Editorial Policy Checklist.

\section{Statistics}

For all statistical analyses, confirm that the following items are present in the figure legend, table legend, main text, or Methods section.

n/a Confirmed

Х $\square$ The exact sample size $(n)$ for each experimental group/condition, given as a discrete number and unit of measurement

$\triangle \square$ A statement on whether measurements were taken from distinct samples or whether the same sample was measured repeatedly

$\square$ The statistical test(s) used AND whether they are one- or two-sided

$\bigotimes \square$ Only common tests should be described solely by name; describe more complex techniques in the Methods section.

Х $\square$ A description of all covariates tested

Х $\square$ A description of any assumptions or corrections, such as tests of normality and adjustment for multiple comparisons

A full description of the statistical parameters including central tendency (e.g. means) or other basic estimates (e.g. regression coefficient)

$\triangle \square$ AND variation (e.g. standard deviation) or associated estimates of uncertainty (e.g. confidence intervals)

$\triangle$ For null hypothesis testing, the test statistic (e.g. $F, t, r$ ) with confidence intervals, effect sizes, degrees of freedom and $P$ value noted

$\triangle$ Give P values as exact values whenever suitable.

Х $\square$ For Bayesian analysis, information on the choice of priors and Markov chain Monte Carlo settings

Х $\square$ For hierarchical and complex designs, identification of the appropriate level for tests and full reporting of outcomes

$\triangle \square$ Estimates of effect sizes (e.g. Cohen's $d$, Pearson's $r$ ), indicating how they were calculated

Our web collection on statistics for biologists contains articles on many of the points above.

\section{Software and code}

Policy information about availability of computer code

Data collection No custom software was used to collect data in this study. We used the Global Biosphere Management Model (GLOBIOM) to perform the scenario quantification. A summary of model improvements on the nitrogen cycle is provided in the Methods and Supplementary Information. The code will be made available to editors and reviewers upon request. The software used for the scenario quantification was GAMS 25.0.

$\begin{array}{lll}\text { Data analysis } & \text { R scripts used for the scenario analysis will be made available to editors and reviewers upon request. The analysis was performed in } \mathrm{R} \text { version }\end{array}$ 3.5.0 (https://www.r-project.org/).

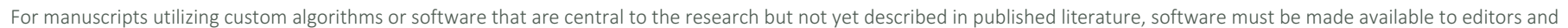

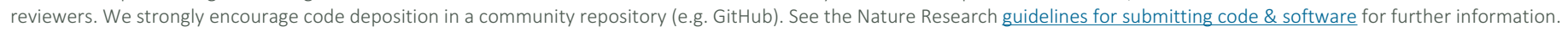

\section{Data}

Policy information about availability of data

All manuscripts must include a data availability statement. This statement should provide the following information, where applicable:

- Accession codes, unique identifiers, or web links for publicly available datasets

- A list of figures that have associated raw data

- A description of any restrictions on data availability

The main data which support the findings of this study will be available at the public Data Repository of the International Institute of Applied Systems Analysis (IIASA DARE; https://dare.iiasa.ac.at/125/; DOI: 10.22022/ibf/07-2021.125). Additional data are available from the corresponding author upon request. Source data for each figure will be also published with the final version of the paper. 


\section{Field-specific reporting}

Please select the one below that is the best fit for your research. If you are not sure, read the appropriate sections before making your selection.

$\square$ Life sciences $\quad \square$ Behavioural \& social sciences $\quad \square$ Ecological, evolutionary \& environmental sciences

For a reference copy of the document with all sections, see nature.com/documents/nr-reporting-summary-flat.pdf

\section{Ecological, evolutionary \& environmental sciences study design}

All studies must disclose on these points even when the disclosure is negative.

Study description

Nitrogen is indispensable in the task of feeding an ever growing and increasingly affluent global human society, but nitrogen losses cause serious ecosystem damage. We investigate this trade-off using an integrated modelling framework and quantify how different nitrogen mitigation options contribute to reconciling food security and compliance with regional nitrogen surplus boundaries.

Research sample

N/A

Sampling strategy

N/A

Data collection

The study largely builds on the datasets available in the standard GLOBIOM model. The additionally collected data are listed in Supplementary Table 1-4 including the reference of the data.

Timing and spatial scale The modeling base year is 2000 and calculated at 10-year steps until 2050, covering global scale.

Data exclusions

No data were excluded from the analyses.

Reproducibility

All the analyses were based on available models and well-defined methods, so the results can be reliably reproduced.

Randomization

Randomization was not relevant for this study.

Blinding

Blinding was not relevant for this study.

Did the study involve field work? $\square$ Yes $\$ No

\section{Reporting for specific materials, systems and methods}

We require information from authors about some types of materials, experimental systems and methods used in many studies. Here, indicate whether each material, system or method listed is relevant to your study. If you are not sure if a list item applies to your research, read the appropriate section before selecting a response.

Materials \& experimental systems

\begin{tabular}{|c|c|}
\hline $\mathrm{n} / \mathrm{a}$ & Involved in the study \\
\hline$\bigotimes$ & $\square$ Antibodies \\
\hline & Eukaryotic cell lines \\
\hline & Palaeontology and archaeology \\
\hline & $\square$ Animals and other organisms \\
\hline & Human research participants \\
\hline & $\square$ Clinical data \\
\hline 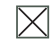 & Dual use research of concern \\
\hline
\end{tabular}

\begin{tabular}{l|l} 
Methods \\
\hline n/a & Involved in the study \\
$\square$ & $\square$ ChIP-seq \\
$\searrow$ & $\square$ Flow cytometry \\
$\square$ & $\square$ MRI-based neuroimaging
\end{tabular}

